\title{
Pliocene and Pleistocene geologic and climatic evolution in the San Luis Valley of south-central Colorado
}

\author{
Karel L. Rogers ${ }^{\mathrm{a}}$, Edwin E. Larson ${ }^{\mathrm{b}}$, Gary Smith ${ }^{\mathrm{c}}$, Danny Katzman ${ }^{\mathrm{c}}$, Gerald R. Smith ${ }^{\mathrm{d}}$, \\ Thure Cerling ${ }^{\mathrm{e}}$, Yang Wang ${ }^{\mathrm{e}}$, Richard G. Baker ${ }^{\mathrm{f}}$, K. C. Lohmann ${ }^{\mathrm{g}}$, Charles A. Repenning ${ }^{\mathrm{h}}$, \\ Penny Patterson ${ }^{\mathrm{i}}$ and Gerald Mackie ${ }^{\mathrm{j}}$ \\ a Department of Biology, Adams State College, Alamosa, CO 81102, USA \\ ${ }^{\mathrm{b}}$ Department of Geological Sciences, University of Colorado, Boulder, CO 80309, USA \\ ${ }^{\mathrm{c}}$ Department of Geology, University of New Mexico, Albuquerque, NM 87131, USA \\ ${ }^{\mathrm{d}}$ Museum of Paleontology, University of Michigan, Ann Arbor, MI 48104, USA \\ ${ }^{\mathrm{e} D e p a r t m e n t ~ o f ~ G e o l o g y, ~ U n i v e r s i t y ~ o f ~ U t a h, ~ S a l t ~ L a k e ~ C i t y, ~ U T ~ 84112, ~ U S A ~}$ \\ ' Department of Geology, University of Iowa, lowa City, IA 52242, USA \\ ${ }^{\mathrm{g}}$ Department of Geological Science, University of Michigan, Ann Arbor, MI 48104, USA \\ h Paleontology and Stratigraphy Branch, US Geological Survey MS 919, Box 25046 Federal Center, Denver, CO 80225 , \\ USA \\ ${ }^{i}$ Department of Geological Sciences, University of Colorado, Boulder, CO 80309, USA \\ j Department of Zoology, University of Guelph, Guelph, Ontario NIG2W1, Canada
}

(Received May 23, 1991; revised and accepted December 11, 1991)

\begin{abstract}
Rogers, K.L., Larson, E.E., Smith, G., Katzman, D., Smith, G.R., Cerling, T., Wang, Y., Baker, R.G., Lohmann, K.C., Repenning, C.A., Patterson P., and Mackie, G., 1992. Pliocene and Pleistocene geologic and climatic evolution in the San Luis Valley of south-central Colorado. Palaeogeogr., Palaeoclimatol., Palaeoecol., 94: 55-86.

Sediments of the Alamosa Formation spanning the upper part of the Gauss and most of the Matuyama Chrons were recovered by coring in the high $(2300 \mathrm{~m})$ San Luis Valley of south-central Colorado. The study site is located at the northern end of the Rio Grande rift. Lithologic changes in the core sediments provide evidence of events leading to integration of the San Luis drainage basin into the Rio Grande. The section, which includes the Huckleberry Ridge Ash (2.02 Ma) and spans the entire Matuyama Chron, contains pollen, and invertebrate and vertebrate fossils. Stable isotope analyses of inorganic and biogenic carbonate taken over most of the core indicate substantially warmer temperatures than occur today in the San Luis Valley. At the end of the Olduvai Subchron, summer precipitation decreased, summer pan evaporation increased, and temperatures increased slightly compared to the earlier climate represented in the core. By the end of the Jaramillo Subchron, however, cold/wet and warm/dry cycles become evident and continue into the cold/wet regime associated with the deep-sea oxygenisotope Stage 22 glaciation previously determined from outcrops at the same locality. Correspondence between the Hansen Bluff climatic record and the deep-sea oxygen-isotope record (oxygen-isotope stages from about 110-18) is apparent, indicating that climate at Hansen Bluff was responding to global climatic changes.
\end{abstract}

\section{Introduction}

The study area for this paper is a high $(2300 \mathrm{~m}$ elevation) mountain desert in Colorado. It lies between the San Juan Mountains, including the Continental Divide, and the Sangre de Cristo

Correspondence to: K. L. Rogers, Department of Biology, Adams State College, Alamosa, CO 81102 , USA.
Mountains, one of the front ranges of Colorado (Fig. 1). Fossiliferous sediments are from the PlioPleistocene Alamosa Formation (Siebentha1, 1910) that form the almost flat floor of the San Luis Valley.

Sediments of the Alamosa Formation originated from the San Juan Mountains, the San Luis Hills, and the Sangre de Cristo Mountains (Fig. 1). The San Juan Mountains are underlain almost entirely 


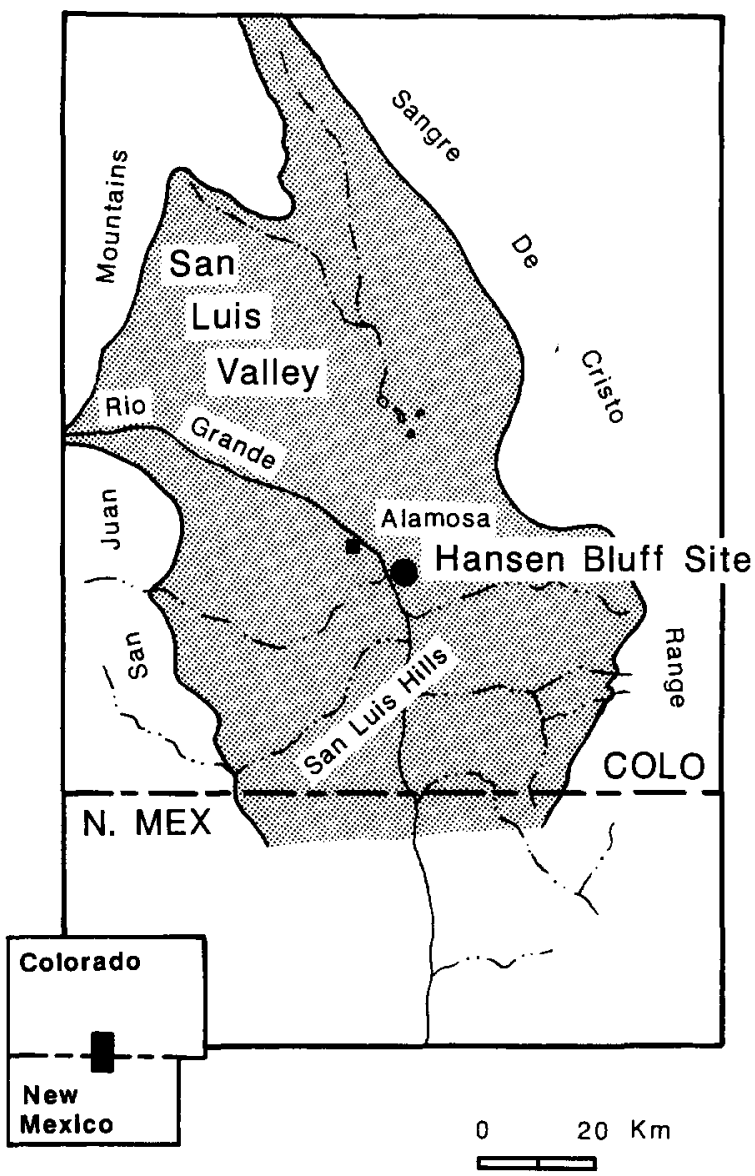

Fig. 1. Location of the study site.

by andesitic lavas and associated volcaniclastic debris, and capped by younger quartz latitic ignimbrites. Precambrian crystalline rocks crop out in a few canyons; they contribute only a small volume of arkosic detritus to San Luis Valley watersheds. In the southern part of the San Luis Valley, the San Luis Hills are composed of andesitic volcanic rocks lithologically similar to those in the San Juan Mountains and basaltic lavas of early rift age (Thompson and Machette, 1989). The Sangre de Cristo Mountains, in contrast, consist principally of Precambrian crystalline rocks, mostly granitic, overlain by Paleozoic sedimentary units; watersheds that drain into the San Luis Valley are currently dominated by crystalline bedrock. Tertiary volcanic rocks occur within the Sangre de Cristo Mountains, but their contribution to the sediment load is minor compared to that derived from the crystalline rocks.
The geology of the San Luis Valley, located in the San Luis drainage basin (i.e. the Rio Grande drainage basin in Colorado), has been studied extensively (see Brister and Gries, in press) because it is at the northern end of the Rio Grande rift (Chapin 1971, 1979, 1988; Cordell, 1978; Hawley, 1978; Tweto, 1979; Keller et al., 1984) and because of its importance hydrologically (Emery, 1971, Moran, 1987). The San Luis Valley is an asymmetric, first-order half-graben that is down-tilted toward the east and bordered by the Sangre de Cristo fault zone (Kirkham and Rogers, 1981). Two second-order half-grabens are present; the Monte Vista graben to the west and the Baca graben to the east are separated by the Alamosa horst (Burroughs, 1981). Today, the San Luis Valley is nearly flat; the Precambrian basement is overlain by Eocene through Pleistocene sediments including the Blanco Basin Formation (Eocene), Conejos Formation (35-30 Ma), a series of ashflow tuffs (26-30 Ma), Santa Fe Group (26-4.5 $\mathrm{Ma}$ ), and Alamosa Formation (Brister and Gries, in press).

The Alamosa Formation thickens from west to east in the San Luis Valley suggesting that accommodation space for sediment was controlled by movement along the Sangre de Cristo fault and that substantive movement along other faults in the area had ceased by mid-Pliocene (Huntley, 1979). Total displacement along the Sangre de Cristo fault since early Miocene has been about $1500 \mathrm{~m}$ (Burroughs, 1981). Holocene movement along this fault ranges from 2.4 to $29.0 \mathrm{~cm} / 1000$ yrs (McCalpin, 1983, Kirkham and Rogers, 1981); rates vary along the fault, with modern movement most pronounced in the southern part of the fault.

Initial study of the only outcrops of the Alamosa Formation began in 1979 at Hansen Bluff (Fig. 1), on the east side of the Alamosa National Wildlife Refuge. Results of an interdisciplinary analysis of the outcrop (Rogers et al, 1985) formed the basis for the present work.

The outcrop sediments were dated by paleomagnetism and the Bishop Ash (0.74 Ma). Deposition occurred in the meandering ancestral Rio Grande, either in slow moving stream channels or in quiet water. Dating of sediments in the $13 \mathrm{~m}$ high bluff was done with an assumption of constant sedi- 
mentation and that the Jaramillo Subchron was just below the reach of sediments available for study. The average accumulation rate calculated from data available in 1985 was $6.9 \mathrm{~cm} / 1000$ yrs.

Analysis of vertebrate and invertebrate fossils and pollen from seven localities and five measured sections resulted in a record of climatic change at Hansen Bluff that could be correlated directly with deep-sea oxygen-isotope stages 22 through 18 .

Three major climatic periods were represented in Alamosa Formation sediments. The oldest was warm/hot and dry, the middle cool and wet but punctuated with a warmer and drier interval, and the youngest was cold and dry.

During the warm/hot and dry period $(0.82-0.81$ $\mathrm{Ma}$ ) the valley floor was a sagebrush grassland; growth rates of fish were similar to modern forms in the Rio Grande River in New Mexico indicating a climate with a freeze-free period between 90 and 200 days; the available aquatic habitat was large and permanent indicating high ground-water levels for the area; warm winters were indicated by three species that occur today in southeast and eastcentral New Mexico (normal winter minimum and mean daily temperatures were probably above -5 and $0^{\circ} \mathrm{C}$, respectively); numerous species characteristic of dry, open, sandy areas were present; mean annual temperature was about $3-8^{\circ} \mathrm{C}$ warmer than today.

Between 0.82 and $0.74 \mathrm{Ma}$, montane forest vegetation occupied the San Luis Valley floor. This indicates a lowering of vegetation zones that would be caused by a $1.2^{\circ} \mathrm{C}$ decrease in mean January temperature, a $1.4^{\circ} \mathrm{C}$ mean July temperature decrease, and a $67 \mathrm{~mm}$ increase in annual precipitation, excluding snowfall. Warm indicator species were absent during this time, and northern forms of freshwater snails were present. The fauna clearly indicated the presence of deep, permanent aquatic habitats. At about $0.77 \mathrm{Ma}$, a slightly warmer and drier interval occurred. Overall, this cold/wet period was interpreted to represent a glacial period punctuated by a short warming trend.

The glacial interval in the deposits was terminated by an erosional surface closely underlain by a reversely magnetized (Matuyama Chron) unidentified ash and ostracod coquina that contains a warm-indicator species (Limnocythere bradburyi).
Above the erosional surface, the Bishop Ash (0.74 Ma) was present in Brunhes magnetically normal sediments.

In deposits younger than $0.74 \mathrm{Ma}$, pollen was absent, but other fossils indicated dry terrestrial conditions. Species indicating warmth were completely absent, and the common fish present were cold-water trout.

The glacial episode starting at about $0.81 \mathrm{Ma}$ was correlated with oxygen-isotope stage 22 and with the classic Nebraskan till in southwestern Iowa. All three are reversely magnetized, in the span between 0.91 and $0.735 \mathrm{Ma}$, and represent the coldest climate during that time.

The Alamosa Formation sediments exposed at Hansen Bluff were formed in a receding basin under circumstances that preserved multiple evidence of climatic oscillations. Thus, it was highly likely that older and fairly-continuous sediments were available in the subsurface. Because the outcrop reflected more than a local climatic record, a core was expected to provide an opportunity to compare a long terrestrial climatic record with the oceanic sequence.

\section{Modern climate and vegetation}

The modern climate and water resources of the San Luis Valley are significantly affected by surrounding mountains, which include 13 of the 53 peaks in Colorado above $4267 \mathrm{~m}$ elevation.

Orographic influences result in an inverse relationship in the amount and seasonality of precipitation between the valley and surrounding mountains. Wetter than average years in the valley correspond to drier than average years in the mountains; most mountain precipitation occurs in the winter whereas most valley precipitation occurs in the summer (Doesken and McKee, 1989). The San Juan Mountains shield the San Luis Valley from moisture coming from the west. Nearly all air masses reaching the San Luis Valley from any direction must descend over mountain barriers. The descending air, especially in the winter, compresses and results in loss of relative humidity and warming. During warm times, especially late spring and early summer, convection of warm air, enhanced by the presence of mountains, is impor- 
tant in generation of clouds and precipitation on the valley floor (Doesken and McKee, 1989).

Heavy flood-producing rains rarely occur; rainfall of $12 \mathrm{~mm}$ occurs about 3 times per year and events $>25 \mathrm{~mm}$ occur about once every 10 years (Doesken and McKee, 1989). At higher elevations, most precipitation occurs as snow. Flooding in the valley results mainly from heavy, late-season mountain snow storms followed by rapid melting associated with unseasonably warm weather.

The valley floor experiences cold nights with large ranges in diurnal and seasonal temperatures (Doesken and McKee, 1989). Thin cloud cover leads to rapid radiative cooling in the evenings causing dense cold air to settle on the valley floor. The coldest temperatures are reached when the sky is clear and the ground is snow-covered. Temperatures become more moderate toward the perimeter of the valley. Although cloud cover causes moderation of temperatures, only about 80 days per year are classified as cloudy by the National Weather Service.

In the mountains, precipitation increases and evaporation decreases with increasing elevation. At the valley floor, evaporation exceeds precipitation. Nevertheless, it is less than expected in such a dry environment because of the cool nights. See Table 1 for a summary of climatic indicators.

The dominant vegetation zones from low to high elevation in the mountains include pinonjuniper, ponderosa pine, and spruce-fir forests, and tundra. The valley floor vegetation is now dominated by greasewood (Sarcobatus) and rabbitbrush (Chrysothamnus); before about 1925, the valley was covered by grasses and sagebrush (Artemisia) (O. Silzell, oral commun., 1984). Today, Hansen Bluff is near a floodplain wetland with oxbow lakes bordering the Rio Grande River. The wetland has scattered cattails (Typha), cottonwoods (Populus), grasses, sedges (Carex), and willows (Salix).

\section{Coring and methodology}

A core from the base of Hansen Bluff (taken immediately below measured section D of Rogers et al, 1985) was recovered in 1986 by rotary drilling with a five foot long $(1.524 \mathrm{~m})$, split-tube core barrel (size NC; 2.40 inch or $6 \mathrm{~cm}$ inside diameter).

\section{TABLE 1}

Synopsis of climatic variables in the San Luis Valley. Data taken from Doesken and McKee (1989), the National Climatic Data Center (1982), and the Alamosa National Weather Service (pers comm., 1991).

\begin{tabular}{|c|c|c|}
\hline \multicolumn{2}{|l|}{ Temperature* } & Precipitation* \\
\hline Mean annual & $5.3^{\circ} \mathrm{C}$ & Mean annual $178 \mathrm{~mm}$ \\
\hline Mean monthly & & Mean monthly \\
\hline Jan & $-8.0^{\circ} \mathrm{C}$ & Oct-Apr \\
\hline July & $18.3^{\circ} \mathrm{C}$ & May-Sep $109 \mathrm{~mm}$ \\
\hline Record high & $33.9^{\circ} \mathrm{C}$ & Record high $293 \mathrm{~mm}$ \\
\hline Record low & $-45.6^{\circ} \mathrm{C}$ & Record low $\quad 86 \mathrm{~mm}$ \\
\hline $\begin{array}{l}\text { Mean diurnal } \\
\text { temp. range }\end{array}$ & $18.0^{\circ} \mathrm{C}$ & Solar Radiation* \\
\hline $\begin{array}{l}\text { Mean frost- } \\
\text { free days }\end{array}$ & $\sim 86 / \mathrm{yr}$ & $\begin{array}{l}\text { Cloudiest Nov-Dec } \\
\text { Sunniest Mar-Sep }\end{array}$ \\
\hline Evaporation* & & Solar radiation is less \\
\hline Mean rel. humidity & $42 \%$ & than $60 \%$ clear day \\
\hline Mean July humidity & $28 \%$ & values $30-40$ days $/ y r$ \\
\hline May-Oct pan evap. & $\begin{array}{l}192 \\
\mathrm{~cm} / \mathrm{sum}\end{array}$ & $\begin{array}{l}\text { Some cloudiness occurs } \\
\text { on more than } 50 \% \text { of } \\
\text { the days of the year }\end{array}$ \\
\hline
\end{tabular}

*Values are given at Alamosa. The climate becomes warmer, wetter, and with closer temperature extremes at the perimeter of the San Luis Valley.

Because of topographic variability, overlap of about $6.4 \mathrm{~m}$ occurs between the core and the lowest beds studied in the outcrop. A depth of 127 $m$ was reached, with an average recovery of $72 \%$. Core (Fig. 2) was lost at the top of each $1.524 \mathrm{~m}$ drilling interval by the washing necessary to keep the casing free of sand. During drilling, color changes of the drill water were recorded to provide independent depth indications of major lithologic breaks. After each core segment was brought to the surface, the core was labeled, photographed, measured, marked for depth, evaluated for missing sections, and the lithology was described. Lastly, each core segment was wrapped in plastic film and stored in a sealed PVC tube.

In the laboratory each core segment was split lengthwise. For identification of ash beds, small $(20 \mathrm{cc})$ samples were obtained from all intervals that were light gray. Five cc samples were taken from fine-grained sediments for analysis of diatoms but none contained identifiable diatoms (Bradbury, pers. commun., 1990). Forty cc samples were taken for pollen analysis. The samples were processed with standard laboratory methods for clastic sedi- 


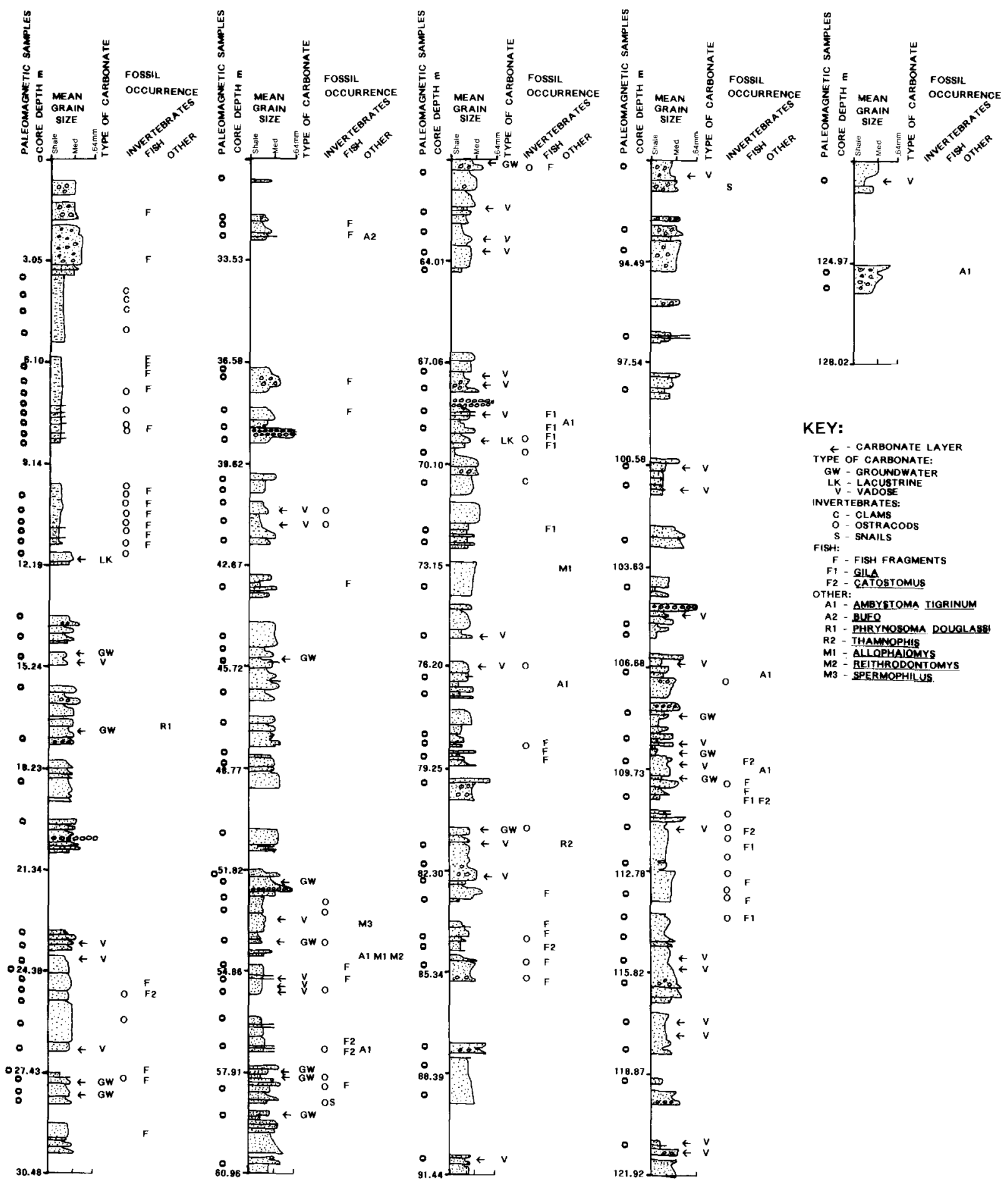

Fig. 2. Lithology, mean grain size, missing core, location and type of carbonate layers, placement of paleomagnetic samples, and location of invertebrate and vertebrate fossils in the Hansen Bluff core. 
ment, i.e. $\mathrm{KOH}, \mathrm{HCl}, \mathrm{HF}$, and acetolysis solution augmented by screening with a $7 \mu \mathrm{m}$ sieve, and flotation with $\mathrm{ZnCl}_{2}$. Pollen samples were mounted in silicon oil ( 2000 centistokes), and pollen was identified by comparison with the reference collection at the University of Iowa Geology Department. For the analysis of ostracods, $20 \mathrm{cc}$ samples were collected from all layers that tested positive for carbonate with dilute $\mathrm{HCl}$. These samples were washed through 100 mesh screen, and the residues were hand picked under a binocular microscope. Species were identified by comparison with a set of reference slides, under the supervision of R.M. Forester (U.S. Geol. Surv. Denver).

Approximately 130 paleomagnetic samples were taken from the finer-grained beds, muds to silts rarely fine sands (Fig. 2). Samples were taken in small plastic cubes (Rosenbaum and Larson, 1983), oriented with respect to vertical. Each cube was pushed into the face of the split core section close to the core centerline. A plastic cap was attached and sealed to minimize desiccation. All remanence measurements were made on a Schonstedt SSM $1 \mathrm{~A}$ spinner magnetometer. Following natural remanent magnetization (NRM) measurement, all samples were subjected to progressive alternatingfield (AF) demagnetization at 5, 10, 15, and 20 $\mathrm{mT}(1 \mathrm{mT}=10$ Oe). After AF demagnetization at $20 \mathrm{mT}$, the remanence intensities of many samples became so low that demagnetization was discontinued.

Seventy-five percent of the remaining core was washed in $15 \mathrm{~cm}$ segments through 50 mesh screen; the residue was hand picked under a dissecting microscope to obtain fossils. In addition to the fossils described in this paper, plant remains and insect parts were collected; none were identifiable.

The remaining core was described in detail, with close attention to sedimentary structure and depositional features. Representative lithologies were sampled for petrographic examination. Preference was given to medium and coarse-grained sands although some fine- and very fine-grained sands and mudstones were also sampled to provide more complete coverage. Thin sections were prepared by impregnating unconsolidated sands with epoxy and staining with sodium cobaltinitrite and barium chloride rhodizonate to facilitate identification of potassium feldspar and plagioclase, respectively. Modal analyses were performed by counting 300 points per slide using the Gazzi-Dickinson method (Ingersoll et al., 1984) to minimize mineralogical variations related to grain size.

All inorganic carbonate layers and nodules from the core were sampled and classified as lacustrine, vadose, or groundwater in origin; no inorganic carbonates from the outcrop were sampled. Inorganic carbonate samples were baked in vacuo at $450^{\circ} \mathrm{C}$ and then reacted with $100 \%$ phosphoric acid. The resulting $\mathrm{CO}_{2}$ was cryogenically separated and analyzed on a mass spectometer.

Carbon and oxygen isotopic data were collected on ostracod and mollusc samples from all core layers containing concentrations and from samples recovered in $15 \mathrm{~cm}$ washed segments. Because biogenic isotope data had not been collected previously on outcrop material, samples were processed and analyzed. Stable-isotope data from ostracods are affected by species and by developmental stage. In this study, ostracods were sorted by size but not by species before analysis. Most isotope analyses were done on Candona patzcuaro, which was present in almost every sample and the largest species available. Biogenic carbonate samples ranging in weight from 100 to $300 \mu \mathrm{g}$ were roasted at $380^{\circ} \mathrm{C}$ to remove volatile contaminants. Samples were individually treated with four drops of anhydrous phosphoric acid at $73^{\circ} \mathrm{C}$ in a Finnigan 'Keil' extraction system coupled directly to the inlet of a MAT 251 ratio mass spectrometer. Isotopic enrichments were corrected for acid fractionation and ${ }^{17} \mathrm{O}$ contribution. Precision and calibration of data were monitored through daily analysis of NBS-20 powdered carbonate that bracket sample analyses. Measured precision was above $0.1 \%$ for both carbon and oxygen isotope compositions.

Biogenic and inorganic isotopic results are given in the per mil (\%) notation where:

$\delta^{13} \mathrm{C}(\%)=\left(\mathrm{R}_{\text {sample }} / \mathbf{R}_{\mathrm{PDB}}-1\right) \times 1000$ and $\mathrm{R}$ is the ratio of ${ }^{13} \mathrm{C} /{ }^{12} \mathrm{C}$ in the sample or the PDB standard, respectively. Ratios for $\delta^{18} \mathrm{O}$ are calculated in an analogous fashion.

The remainder of the core is stored at Adams State College. All fossils have been accessioned to 
the University of Colorado Museum, Boulder, Colorado.

\section{Data}

\section{Geochronology}

Two stratigraphically separated, well-dated ash beds in the Hansen Bluff sequence provide the basis for establishing a polarity magnetostratigraphy in the cored section: the $0.74 \mathrm{Ma}$ Bishop Ash, identified in surface exposures at Hansen Bluff, and the $2.02 \mathrm{Ma}$ Huckleberry Ridge Ash at 78.3 $\mathrm{m}$ depth in the core. The latter ash, light gray and $30 \mathrm{~cm}$ thick, has been identified on the basis of shard shape, mineral content, and trace-element chemistry (Izett, pers comm., 1988). The Huckleberry Ridge Ash has not been previously reported in Colorado (Izett and Wilcox, 1982).

Because the core was obtained by rotary drilling, all of the oriented paleomagnetic samples lack azimuthal control. Magnetic polarity determinations of the samples, therefore, were based solely on remanence inclinations. NRM directions are dominated by normal polarity (downward) inclinations, but with progressive demagnetization, reversed and intermediate (steep upward, low upward or low downward) inclinations became more common (compare Fig. 3: $10 \mathrm{mT}$ and 20 $\mathrm{mT}$ ). Three intervals maintained normal polarities and strong intensities during all steps of demagnetization. The remaining intervals, comprising nearly $3 / 4$ of the section, exhibited reversed to intermediate directions interrupted by spikes of normal polarity. Moreover, with progressive AF demagnetization, directions in $83 \%$ of these samples moved away from normal toward intermediate or reversed directions. The spikes of normal polarity remaining after AF cleaning to $20 \mathrm{mT}$ are considered to represent stable remanent magnetization acquired after deposition.

\section{Sedimentary Analysis}

Five parameters of sediment composition reflect stratigraphic variation in provenance (Fig. 4). The total volcanic lithic content is sensitive to input from the San Juan Mountains and the San Luis Hills. The andesite to andesite plus ignimbrite ratio is high and nearly constant throughout the core, indicating that the streams from the San Juan Mountains incised through capping ignimbrites and underlying andesites during sediment deposition. Because andesitic detritus probably dominated San Juan sediment of the core, the few percent of quartz and sanidine present in the capping ignimbrites (Lipman, 1975) probably did not substantially contribute to the quartz content. Quartz and potassium (K) feldspar in the sediments must have been derived almost exclusively from the crystalline rocks of the Sangre de Cristo Mountains. The quartz and K-feldspar measures thus provide an indication of Sangre de Cristo influence. A second measure of San Juan influence can be seen in the plagioclase to total feldspar plus quartz ratio. Because plagioclase could be derived from both provenances, but significant K-feldspar and quartz only from the Sangre de Cristo source areas, higher ratios should reflect increased San Juan influence.

Hand-lens observations of sands in the core coupled with petrographic data indicate two general facies associations. Therefore, broad sections of core were classified as channel or floodplain The classification of each $30 \mathrm{~cm}$ segment was used to calculate the range of percent channel deposits; all missing core was counted as channel for a high estimate and as floodplain for a low estimate. These data, along with the percents calculated by ignoring missing core, are plotted within magnetic control points in Fig. 5. Regardless of the three measures used, floodplain facies are most abundant above $21 \mathrm{~m}$ depth in the core.

Channel facies, representing deposition in river channels and on sand bars, are dominated by medium- to coarse-grained sands, commonly in fining-upward units capped by fine-grained sands. The tops of some fining-upward sequences contain root traces. Beds, which range in thickness from 0.3 to $1.5 \mathrm{~m}$, are generally cross-stratified. Many channel sands are cemented by calcite, typically at contacts between finer- and coarser-grained units (Fig. 2).

Floodplain sequences are dominated by fine- to very fine-grained sands and muds. Preserved depositional structures are uncommon and root traces and carbonate nodules are abundant. Beds are generally less than $0.3 \mathrm{~m}$ thick. 


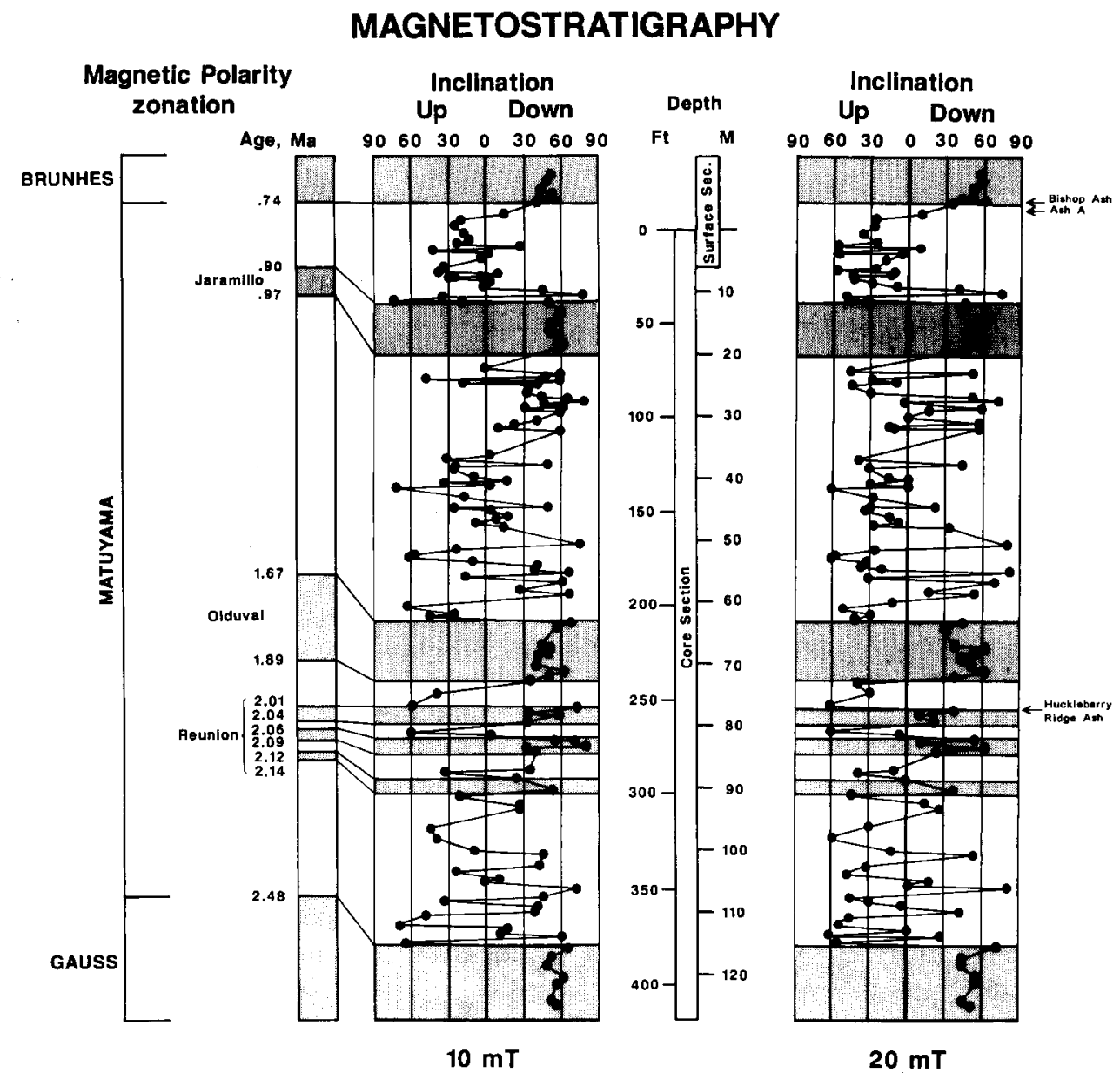

Fig. 3. Magnetostratigraphic interpretation of the Hansen Bluff core sediments (shaded represents normal polarity; unshaded, reversed).

Within the broad categories of channel and floodplain facies, sediments at Hansen Bluff record a variety of environments of deposition. Thick beds typically fine upward from medium- to very fine-grained sands and may represent large flood events, crevasse splays, or small floodplain channels. Thin $(5-10 \mathrm{~cm})$ rhythmically bedded fine sand and silt beds may represent flood-slackwater sediments such as those described along modern river courses (Kochel and Baker, 1988). Green silts and fine sands, commonly associated with carbonate nodules and ostracod concentrations, suggest deposition on floodplain wetlands. Deposition of these sequences may form distal to alluvial ridges because they typically occur near the middle of floodplain deposits that fine both upward and downward. Other facies sequences, $0.5-1.0 \mathrm{~m}$ thick and coarsening upward, may represent lateral progradations of levees along the margin of the alluvial ridges.

Excluding lacustrine carbonate, which is laminated and interbedded with sand and silt, carbonate layers and nodules are abundant in the core sediments (Fig. 2). They were probably formed at the phreatic-vadose interface, although not necessarily in active soil profiles (Fig. 6). Pedogenic carbonate with meniscus or pendant form is absent in coarse grained sediment; Carbonate in the Hansen Bluff core typically forms a relatively uniform micritic coating on the detrital grain surfaces surrounded by fine-grained spar.

Root traces are abundant in the sediments; plant 


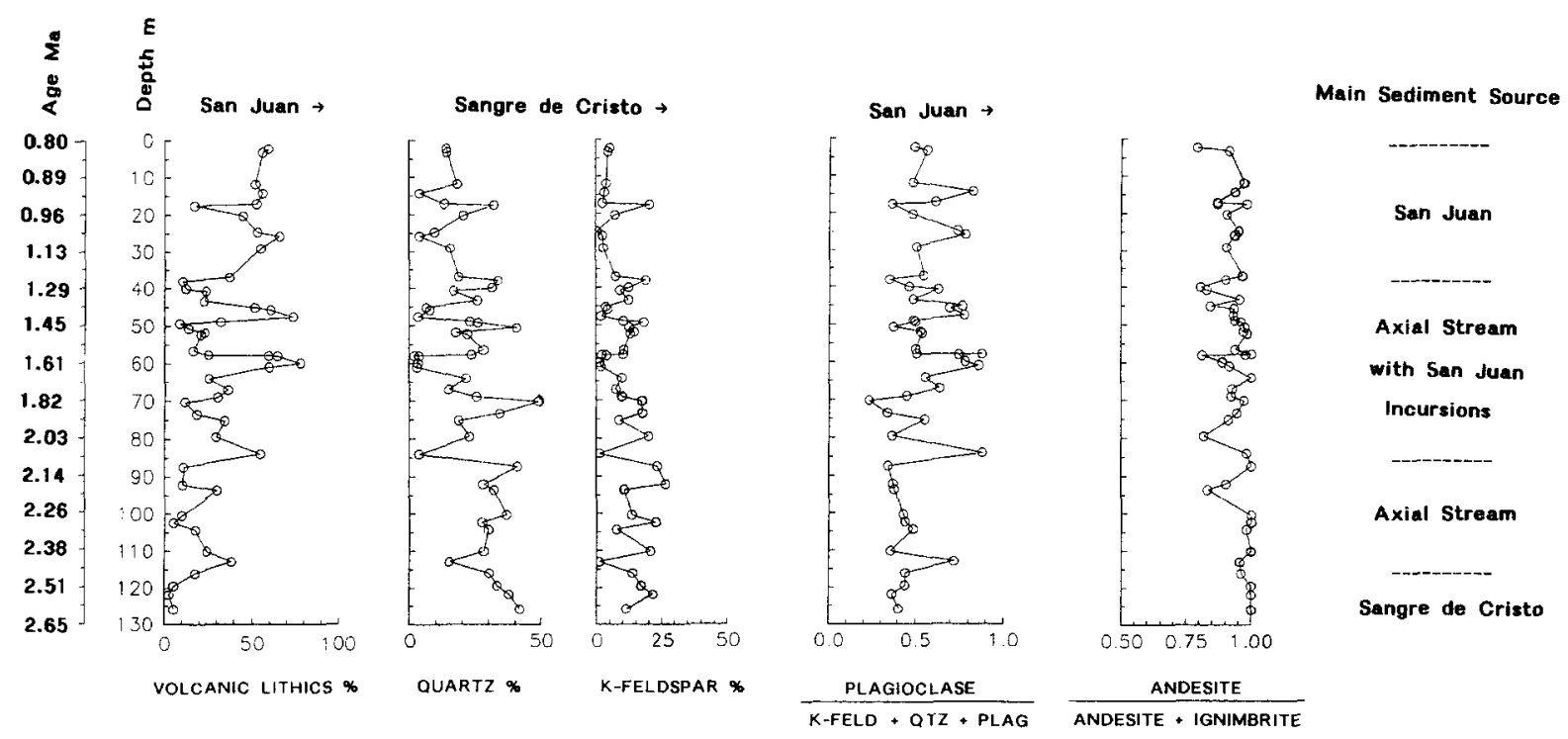

Fig. 4. Stratigraphic variation in sediment composition. San Juan source areas are dominated by volcanic lithics and Sangre de Cristo source areas are dominated by quartz and $\mathrm{K}$-feldspar.

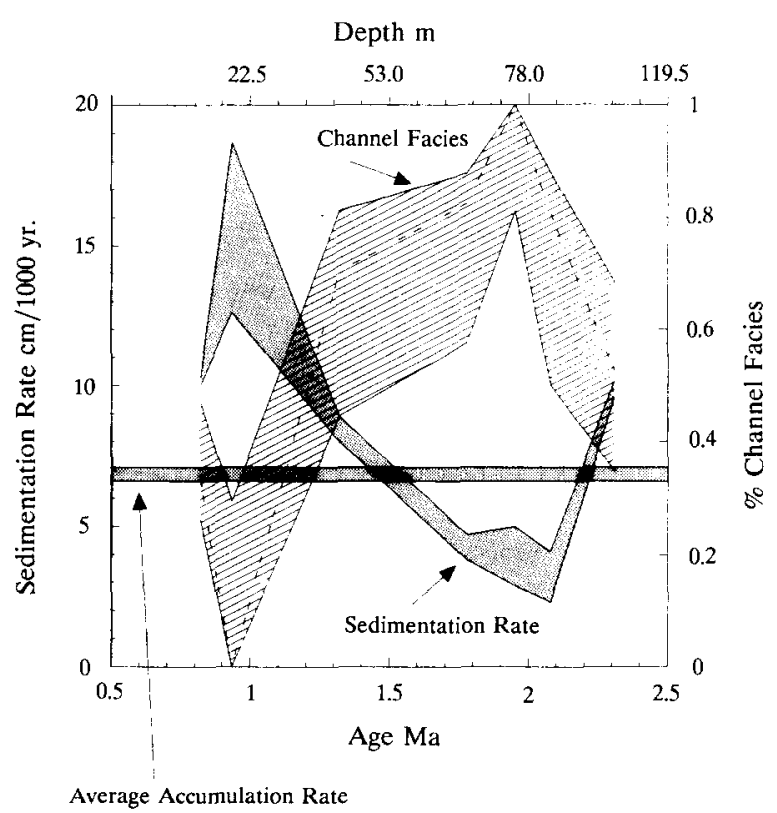

Fig. 5. High and low sedimentation rates within paleomagnetic control points. Percent of channel facies also shown, with high estimate based on all missing core being channel facies, and low estimate based on all missing core being floodplain facies. Actual percent in the recovered core is also plotted. An inverse relationship between sedimentation rate and channel facies ratio is apparent. Average accumulation rate was calculated by sedimentation between ash layers and between the bottom of the Brunhes Chron and the top of the Gauss Chron. growth apparently occurred on mid-channel bar tops and point bars, in floodplain marshes, and on floodplains that dried entirely during a portion of each year. The length of time sediments may have undergone pedogenic modification at the surface can be tentatively inferred from the degree of alteration of the detrital grains. Throughout the core, detrital plagioclase and ferromagnesian silicate grains have undergone only minor dissolution (Fig. 7). This degree of alteration is less than that observed in 10,000 year old soils formed under similar climatic conditions (Birkland, 1984). Moreover, the uniform character of the minimal postdepositional modifications suggests most of the alteration did not occur during intermittent soilforming intervals. Hence, the maximum span of surficial exposure for any of the sediments probably was less than a few thousand years.

Carbonate precipitation in most cases appears to have occurred at relatively shallow depths below the existing ground surface (Fig. 6). Most of the carbonate probably formed at the top of the phreatic zone by evaporative processes at the capillary fringe. In some cases, channel sands are well cemented by calcite at contacts between finer- and coarser-grained sediments; this occurrence suggests that the calcite represents major permeability boundaries. 


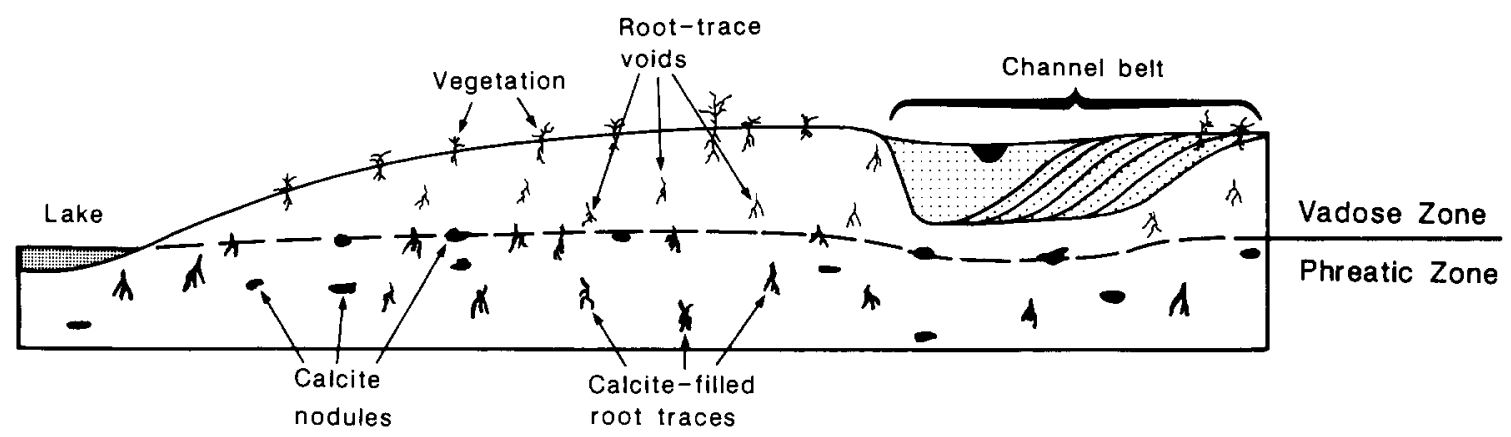

Fig. 6. Diagrammatic representation of the inferred development of calcite nodules and calcite-filled root traces at the vadosephreatic interface. Dimensions: vertical, tens of meters and horizontal, $500-1000 \mathrm{~m}$.

There is no petrographic evidence of cementation by carbonate long after deposition. The extent and types of alterations throughout the core are uniform so diagenetic processes during burial occurred only over relatively wide stratigraphic intervals.

Therefore, three types of carbonate appear to be present. Lacustrine and groundwater carbonates most likely reflect groundwater chemistry. Vadose carbonate, on the other hand, was probably formed under the combined influence of groundwater chemistry and plants.

\section{Paleontology}

Six species of ostracods occur in 48 levels of the Hansen Bluff core (Fig. 2). They include: Limnocythere bradburyi, L. robusta, $L$. ceriotuberosa, $L$. platyforma, Candona patzcuaro, and $L$. n.sp.A. Limnocythere n.sp.A may be ancestral to L. bradburyi (Forester, pers comm., 1990); it shares characteristics of $L$. bradburyi and $L$. robusta. Distribution and relative abundance of ostracod species within the core section are presented in Fig. 8.

The Hansen Bluff limnocytherids are characteristic of lakes and ponds in which evaporation is equal to or exceeds precipitation (Forester, oral comm., 1990). Characteristic water bodies are fresh to saline, permanent to emphemeral ponds and lakes. Individual species have specific ecological requirements.

Limnocythere bradburyi is a warm indicator species; its modern biogeographic distribution is in central Mexico and south of the frostline in the
United States (Forester, 1987). In the past, it has occurred much farther north; it may be able to survive colder winters if it occurs in lakes deep enough to remain near $0^{\circ} \mathrm{C}$ in winter, but shallow enough to warm during summer (Forester, 1985, 1987).

Limnocythere robusta has never been found living, but may not be extinct. From fossil associations, $L$. robusta probably lives in lakes similar to those of $L$. bradburyi, but it may tolerate colder water (Forester and Bradburyi, 1981, Forester, pers. comm., 1990).

The coolest indicator of the limnocytherids present in the core is $L$. ceriotuberosa, which lives only north of the frostline in North America today (Forester, 1987). Forester (1987) hypothesizes this species requires a cold period during part of its life cycle, perhaps in the egg stage. This ostracod lives in the San Luis Valley today in the ephemeral, saline San Luis Lake.

Limnocythere bradburyi and L. ceriotuberosa can coexist under some conditions, e.g., $9.9 \mathrm{~m}(0.89$ $\mathrm{Ma}$ ) in the Hansen Bluff core, in the Hansen Bluff outcrop near the end of the Stage 22 glaciation and at San Agustin Plains, New Mexico between about $18-14 \mathrm{Ka}$. Co-occurrence may result from the two species living or surviving in different places in the same lake (Forester, 1987). For example, Limnocythere bradburyi might survive in the center of permanent lakes buffered from cold winter temperatures while $L$. ceriotuberosa might live in the colder littoral or sublittoral zones. Cooccurrence of these taxa in a northern lake suggests the lake was permanent but shallow, such that the deepest waters were sufficiently warm during summer allowing $L$. bradburyi to complete its life cycle. 

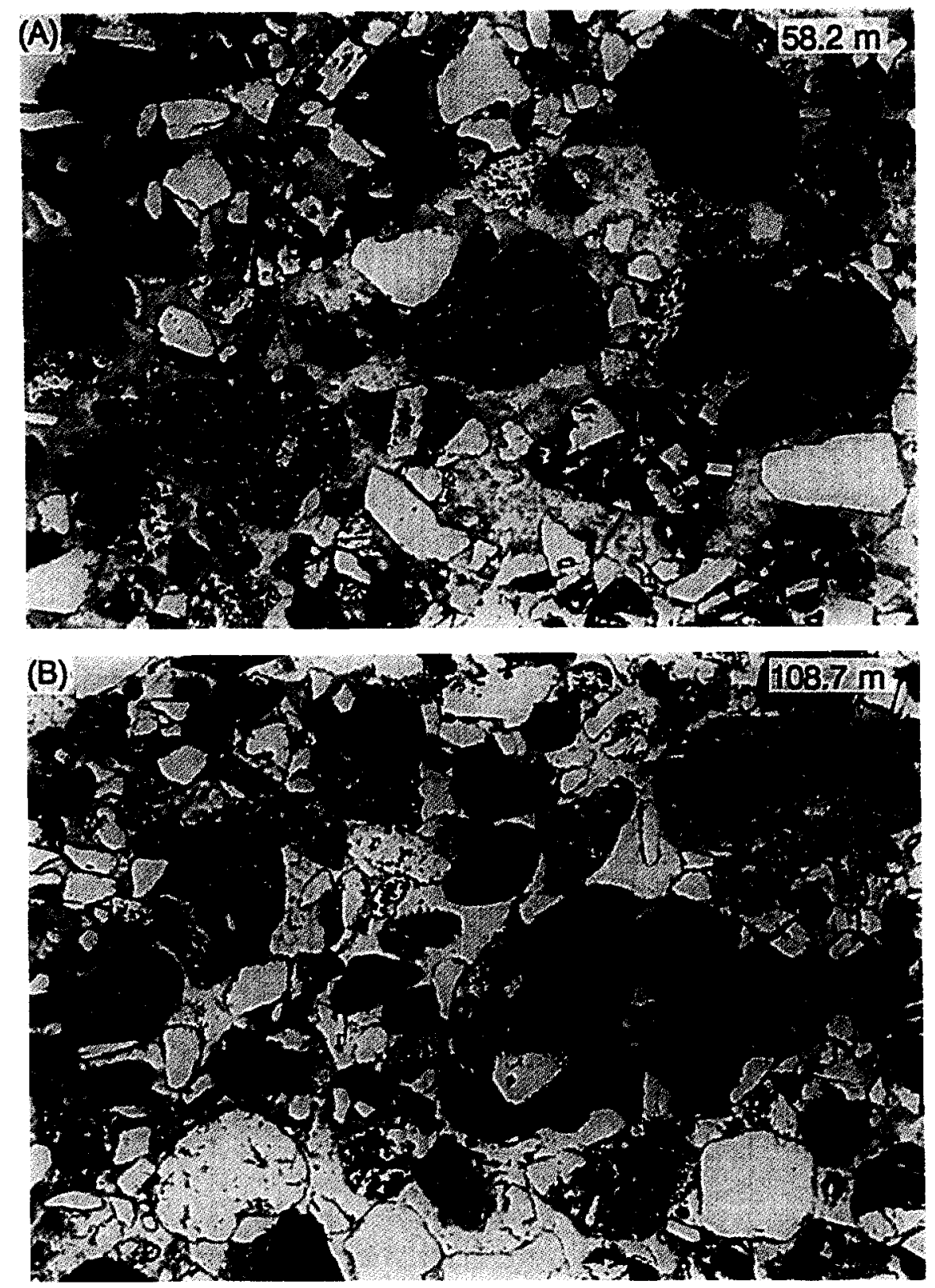

Fig. 7A. Photomicrograph showing the general lithologic character of the volcanic-rich sandstones from the upper portion of the Hansen Bluff core. Note that the detrital framework constituents have not undergone in situ alteration. Sample obtained from core depth $58.2 \mathrm{~m}$; field of view $2.9 \mathrm{~mm}$. B Photomicrograph showing the unaltered character of the volcanic-rich sandstones from the lower portion of the cored interval. Sample obtained from core depth $108.8 \mathrm{~m}$; field of view $2.9 \mathrm{~mm}$.

According to Forester (oral. commun., 1990), Limnocythere platyforma may indicate water freshening, probably from increased precipitation that causes more stream discharge in the catchment basin.

Candona patzcuaro is present in nearly every ostracod assemblage in the core. This species tolerates a broad range of salinities, but differs from the other ostracods at Hansen Bluff in that it can survive desiccation through torpidity (Delorme and Donald, 1969). Today C. patzcuaro occurs in the San Luis Valley interdune lakes. 


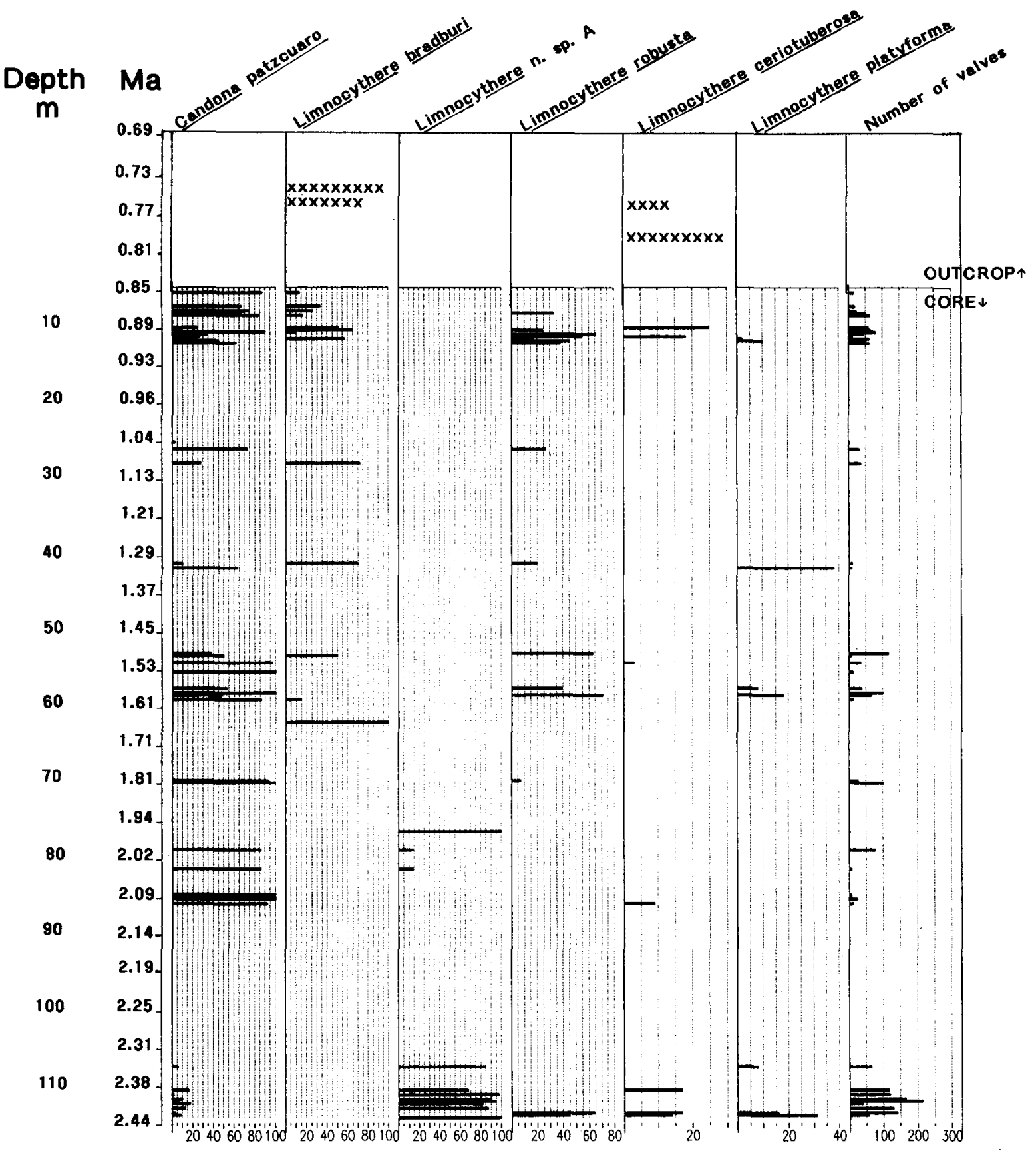

\section{Percent}

Fig. 8. Ostracod frequency by depth in the Hansen Bluff core. Climatically important species from the outcrop are also shown. Data are presented as a percentage of the number of valves recovered. Only concentrations of ostracods are included. 
Clams are present in the core in four $15 \mathrm{~cm}$ long segments from 3.66-4.57 m depth (Fig. 2). Species include the widespread and tolerant Pisidium casertanum and $P$. compressum, which are characteristic of perennial well-oxygenated waters. Another bivalve, Sphaerium of $S$. similie, occurs in the core at a depth of $70.7 \mathrm{~m}$ (Figure 2). The Sphaerium fragments have coarse, evenly-spaced striae that are characteristic of $S$. similie and resemble those on occasional shells of Sphaerium striatinum, a species with a broad North American distribution. Sphaerium similie has not been previously reported in the west; today it is confined to the east-central half of North America. The fragments from Hansen Bluff are insufficient to establish a range extension for the species.

Aquatic snails occur at $59.1 \mathrm{~m}$ (Physid fragment), and $92.4 \mathrm{~m}$ (Gyraulus parvus) in the core (Fig. 2). Gyraulus parvus is a widespread North American species common in perennial welloxygenated waters.

Fossil fish-bone fragments are very common at Hansen Bluff, occurring in fifty-nine $15 \mathrm{~cm}$ segments of the core; all are minute bones and teeth from fishes less than $15 \mathrm{~cm}$ in length. In 14 of the segments, fish remains are identifiable (Fig. 2). All of the identifiable bones are from either Gila $\mathrm{cf}$. G. pandora, the Rio Grande chub (a minnow, family Cyprinidae), or one of two kinds of mountain sucker (Catostomus subgenus Pantosteus, family Catostomidae); unidentifiable fragments probably represent the same three species. These three species were found in outcrop sediments older than $0.74 \mathrm{Ma}$. All are warm-water indicators whose geographic ranges are primarily south of the San Luis Valley. Gila pandora lives in New Mexico; Catostomus plebeius is found widely in the Rio Grande Basin. Based on the shapes of the maxilla and dentary, one of the suckers (Catostomus ' $a$ ' of Rogers et al., 1985) is related to forms described by Siebert and Minckley (1986) from the northern Sierra Madre Occidental of Mexico.

Amphibian fossils occur in seven segments of the core and two segments contained reptile fossils (Fig. 2). Species include Ambystoma cf. A. tigrinum (tiger salamander - vertebrae, ribs, leg bones, and a dentary) and Bufo sp. (toad - vertebra). Both forms occur in the San Luis Valley today. Reptile species include Phrynosoma douglassi (short horned lizard - anterior portion dentary) and Thamnophis sp. (garter snake - fragmentary vertebra). Short horned lizards occur today in dry-shrubby areas of the San Luis Valley; this species was present in the outcrop only during dry, cold times.

Three species of mammal fossils occur in three segments of the core (Fig. 2). Species include Spermophilus sp. (small ground squirrel - lower molar from $53.34 \mathrm{~m}$ depth), Reithrodontomys sp. cf. $R$. megalotis (harvest mouse - mandibular ramus with three molars and an incisor from $54.56 \mathrm{~m}$ depth), and Allophaiomys (extinct microtine rodent - incomplete first lower molar from 54.56 $m$ depth and complete third lower molar from 73.1 m depth). Spermophilus and Reithrodontomys suggest the presence of a mountain meadow environment. The latter, in particular, normally inhabits thick, overgrown grass but can live in adjacent open forests; it is especially abundant in wet areas. This may be the oldest fossil record, although other (extinct) species are known to be more than $4 \mathrm{Ma}$ old. Allophaiomys, although extinct, has a fossil distribution that indicates it was more tolerant of humid, subtropical climates, and less tolerant of cold climates, than was its descendant, the genus Microtus (Repenning, 1990), present in the outcrop sediments. By analogy to faunas in the Great Plains, the presence of Allophaiomys in the two core intervals suggests that during those times winter freezes were uncommon, rainfall was high, and summers included many cloudy days with moderate temperatures (Repenning, 1990). The fossil from $73.1 \mathrm{~m}$ depth in the Hansen Bluff core is the oldest record of Allophaiomys in North America. It is smaller and identical to some individuals of Allophaiomys pliocaenicus Kormos (1932) from the type locality, Betfia-2 or Puspokfurdo, Romania (Fig. 9).

\section{Palynology}

The top $11.6 \mathrm{~m}$ of core contained pollen; these data are presented along with the surface outcrop data analyzed by Hall (Rogers et al, 1985) in Figure 10.

Pollen from a surface sample (Fig. 10) reflects the modern vegetation of the San Luis Valley 
A

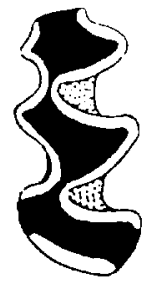

Fig. 9A. Allophaiomys cf. pliocaenicus fossil from 73.15-73.30 $\mathrm{m}$ depth in the Hansen Bluff core (1.89 Ma) B. Topotype of Allophaiomys pliocaenicus Kormos, 1932, Betfia-2, Romania.

(Rogers et al., 1985, Jodry et al., 1989). This sample is dominated by species with non-arboreal pollen including Artemisia (sagebrush), Ambrosia (ragweed), Sarcobatus (greasewood), Poaceae (grass), and Chenopodiineae (chenopodsamaranths). The arboreal pollen of Pinus (pine), Picea (spruce), and Juniperus (juniper) with percentages of 19,2 , and 6 , respectively, comes from surrounding mountain slopes.

Pollen spectra from outcrop and core show strong fluctuations over short intervals. High Pinus (and Picea in the outcrop) pollen percentages with low amounts of non-arboreal pollen (NAP) alternate with a decrease in arboreal pollen and very high percentages of Artemisia pollen.

\section{Geochemistry}

Distribution of inorganic carbonates in the Hansen Bluff core with their classifications as lacustrine, groundwater, or vadose are presented in Fig. 2. No data are available from the outcrop.

Inorganic $\delta^{18} \mathrm{O}$ data most likely reflect isotopic composition of meteoric waters (Table 2). The water table in the San Luis Valley presently is at or near the surface; groundwater chemistry should be controlled by local infiltration, including surface and groundwater discharge from the mountains and valley precipitation (Bodrig, 1989). Cerling (1984) reported a good correlation between $\delta^{18} \mathrm{O}$ (PDB) of soil and vadose-zone carbonate and $\delta^{18} \mathrm{O}$ (SMOW) of meteoric water, especially when the carbonate is preserved without diagenetic modification.

Carbon isotopic composition of vadose carbonates were probably affected by plant fractionation. Vadose carbonate $\delta^{13} \mathrm{C}$ data are presented in Fig. 11A; mean values $( \pm 1 \sigma)$ over $15.25 \mathrm{~m}(50$ foot) intervals are given in Fig. 11B. According to Cerling (1984), the carbon-isotopic composition of both soil and vadose-zone carbonates is controlled by the carbon-isotopic composition of $\mathrm{CO}_{2}$ in the soil. This composition of soil and vadose zone

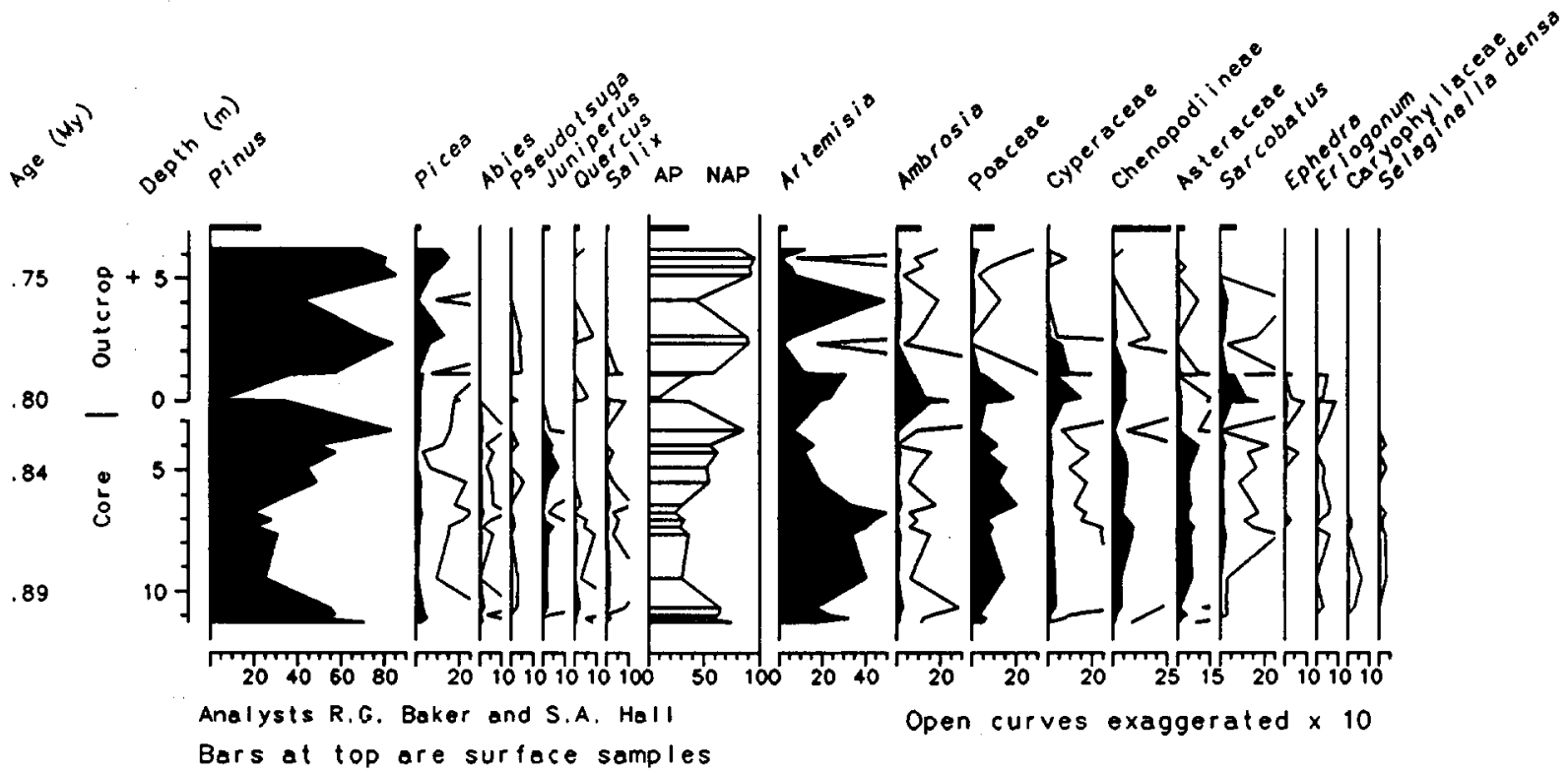

Fig. 10. Pollen diagram including the surface exposures and the top $11.6 \mathrm{~m}$ of the Hansen Bluff core. 
TABLE 2

\begin{abstract}
Biogenic carbon and oxygen stable-isotope data with statistics calculated over $15.25 \mathrm{~m}$ intervals; the outcrop data are treated separately. Inorganic carbonate $\delta^{18} \mathrm{O}$ statistics over similar intervals are presented for comparison.
\end{abstract}

\section{BIOGENIC}

Delta 13 Carbon

\begin{tabular}{|c|c|c|c|c|c|c|c|c|c|c|c|c|c|c|}
\hline Interval & $\left|\begin{array}{l}\text { d13c } \\
\text { mean }\end{array}\right|_{\text {min }}$ & max & std & n & d180 & min & max & std & $n$ & $\begin{array}{l}\text { d180 } \\
\text { mean }\end{array}$ & min & $\max$ & std & $n$ \\
\hline outcrop & $|-9.1|-13$ & 0.4 & $|3.3|$ & 12.0 & -6.9 & -10.3 & $\mid-3.3$ & 2.4 & $\mid 12.0$ & & & & & \\
\hline $0-15.2$ & $1.2 \mid-2.5$ & 3.1 & $|1.5|$ & 17.0 & -1.9 & -5.3 & 0.3 & 1.5 & $\mid 17.0$ & -11.6 & $\mid-11.6$ & $\mid-11.5$ & 10.8 & 2.0 \\
\hline $15.2-30.5$ & $1.2 \mid-0.3$ & 2.9 & $|1.2|$ & 4.0 & -2.1 & -3.1 & $\mid-1.5$ & $\mid 0.6$ & 4.0 & -11.8 & $\mid-13.0$ & $\mid-10.6$ & 0.7 & 6.0 \\
\hline $30.5-45.7$ & $|-1.5|-1.5$ & -1.5 & $|0.0|$ & 1.0 & -5.5 & -5.5 & -5.5 & $\mid 0.0$ & 1.0 & -11.8 & |-12.3 & -11.5 & 0.3 & 3.0 \\
\hline $45.7-61.0$ & $|-1.3|-4.5$ & 1.6 & $|1.5|$ & | 19.0 & -5.0 & -11.0 & $\mid-1.5$ & 2.6 & 19.0 & -11.3 & $\mid-12.5$ & -9.9 & 0.9 & 9.0 \\
\hline $61.0-76.2$ & $|-2.7|-5.8$ & -0.1 & $|2.1|$ & 4.0 & -7.3 & $\mid-11.0$ & -2.3 & $\mid 4.0$ & 4.0 & -11.9 & |-13.3 & $\mid-10.5$ & 0.9 & 10.0 \\
\hline $76.2-91.4$ & $-1.1 \mid-8.3$ & 3.6 & $|3.3|$ & $\mid 13.0$ & -7.5 & $\mid-13.0$ & 1.2 & 4.1 & $\mid 13.0$ & -11.2 & $\mid-12.0$ & $\mid-10.6$ & 0.6 & 5.0 \\
\hline 91.4-106.7 & $|-3.9|-6.8$ & $\mid-0.9$ & 3.0 & 2.0 & -5.9 & -9.5 & -2.3 & 3.6 & 2.0 & -11.8 & $\mid-12.6$ & -10.9 & 0.7 & 5.0 \\
\hline $106.7-121.9$ & $|-3.1|-5.8$ & 2.0 & $|2.3|$ & 10.0 & -6.4 & -14.0 & 1.7 & $|5.1|$ & 10.0 & -11.8 & |-12.9 & $\mid-11.1$ & 0.6 & 13.0 \\
\hline $121.9-127.1$ & & & 1 & & & & & & & -11.3 & |-11.3 & |-11.3 & 0.0 & 1.0 \\
\hline
\end{tabular}

\section{INORGANIC}

Delta 18 Oxygen carbonate is greatly influenced by soil respiration, including the fractionation effects of the three major groups of plants: C3, C4, and CAM (Crassulean Acid Metabolism) (Deines, 1980). C3, C4, and CAM plants have average $\delta^{13} \mathrm{C}$ values of $-27 \%,-12 \%$ and $-18 \%$, respectively. Carbon isotopic composition of modern soil carbonate and coexisting organic matter systematically differ by 14-16\% (Cerling et al., 1989).

Distributions of $\mathrm{C} 3, \mathrm{C} 4$, and CAM plants are controlled by climatic variables. The percentage of C4 grasses in a flora correlates highly with minimum temperatures during the growing season (Teeri and Stowe, 1976), whereas the percentage of $\mathrm{C} 4$ dicots correlates most highly with mean annual (May-October) pan evaporation (Stowe and Teeri, 1978). Nearly half of the known C4 species are grasses (Downton, 1975). Many of the presently known $\mathrm{C} 4$ species belong to genera and families that either have their origins or major parts of their ranges in tropical and subtropical regions; this photosynthetic pathway is an adaptation to warm, intense sunlight and dry climatic conditions. The CAM succulent plant families, Cactaceae and Crassulaceae, are ignored here because they make up only a small portion of plant biomass except in extreme desert conditions.

With the model developed by Cerling (1984), it is possible to estimate the percentage of $\mathrm{C} 4$ plants contributing to carbonate formation from the $\delta^{13} \mathrm{C}$ values of vadose-zone carbonates (Fig. 12). Interpretations of the resulting data based upon the modern observations discussed above are hampered by uncertainty about whether the plant/ climate relationships held true under the different $P\left(\mathrm{CO}_{2}\right)$ conditions (Berner, 1990$)$ in the past. Nevertheless, the data clearly demonstrate the fraction of $\mathrm{C} 4$ biomass was higher in the past than it is now.

Biogenic $\delta^{18} \mathrm{O}$ and $\delta^{13} \mathrm{C}$ data from the core and the outcrop are presented in Fig. 13A,B. Mean, range, standard deviation, and the number of samples for each $15.25 \mathrm{~m}$ section of core and for the outcrop are presented in Table 2. Also presented are similar data for inorganic carbonate $\delta^{18} \mathrm{O}$ values, considered here to be a measure of 
A
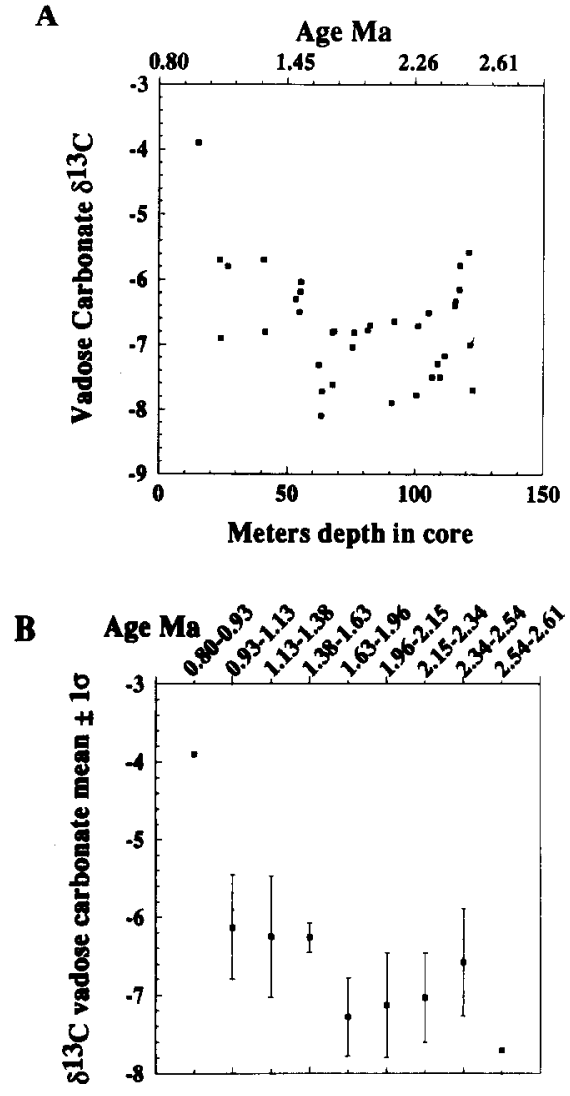

$15.25 \mathrm{~m}$ interval in core

Fig. 11. $\delta^{13} \mathrm{C}$ data from vadose carbonates. A. Raw and B. mean $\pm 1 \sigma$ over $15.25 \mathrm{~m}$ core intervals.

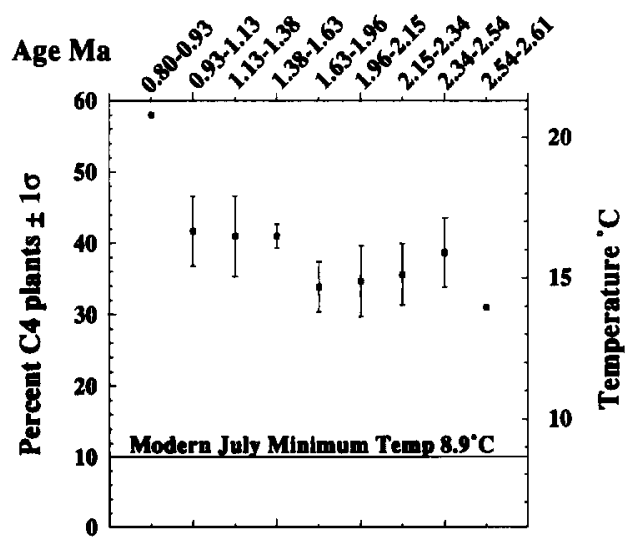

$15.25 \mathrm{~m}$ interval in core

Fig. 12. Percent $\mathrm{C} 4$ plants estimated to have contributed to soil carbonate formation and July minimum temperature inferred if the major $\mathrm{C} 4$ plant influence derives from $\mathrm{C} 4$ grasses.
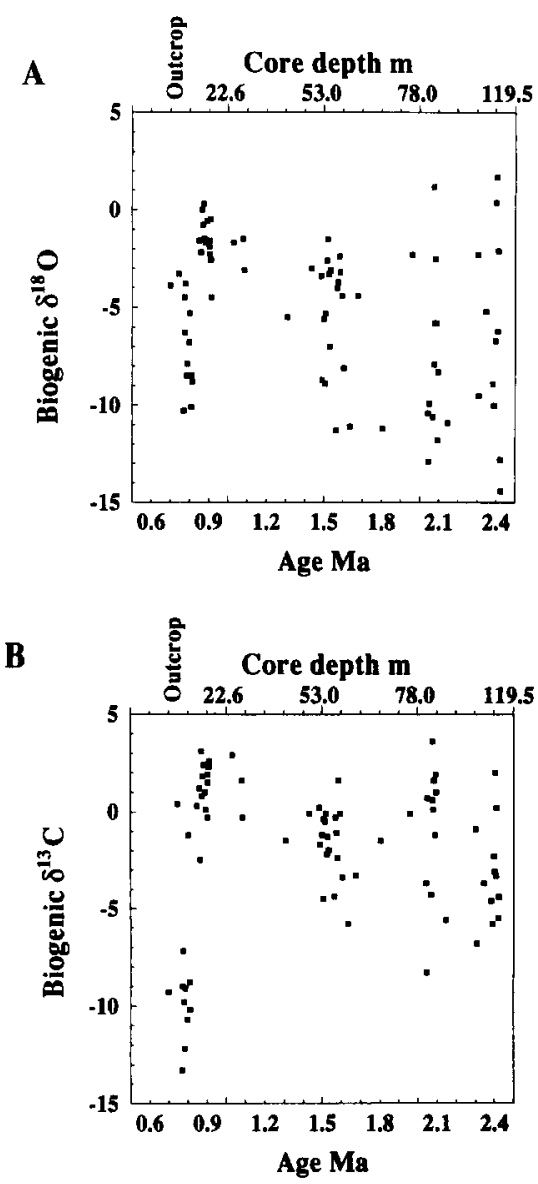

Fig. $13 \mathrm{~A} . \delta^{18} \mathrm{O}$ and B. $\delta^{13} \mathrm{C}$ values from biogenic carbonate. Data include core and outcrop molluse and ostracod samples.

infiltrating meteoric water. Relatively minor variations among sizes and species are indicated by control data from $37 \mathrm{~m}$ in the core based on seven ostracod specimens representing four species and extreme size ranges. Size and species differences account for up to $2 \%$ difference in $\delta^{18} \mathrm{O}$ and $3 \%$ difference in $\delta^{13} \mathrm{C}$. Based on one pair of samples from $10.7 \mathrm{~m}$ in the core, mollusc $\delta^{18} \mathrm{O}$ and $\delta^{13} \mathrm{C}$ values differ from ostracods by about $1 \%$ (more negative in molluscs) in both ${ }^{\delta 18} \mathrm{O}$ and ${ }^{\delta 13} \mathrm{C}$. Thus, trends of biogenic stable-isotope data can be considered accurate to within about $\pm 3 \%$. Five shells of modern Limnocythere ceriotuberosa from the San Luis Lakes have a mean $\delta^{13} \mathrm{C}$ of 0.04 $(\sigma=1.9)$ and a mean $\delta^{18} \mathrm{O}$ of $-4.4(\sigma=0.87)$ (Fig. 13 A,B).

Even within the possible error margin, pronounced differences occur in the magnitude and 
range of biogenic isotope values from the core and outcrop. Values of $\delta^{18} \mathrm{O}$ are most scattered in older sediments; they become more clustered in samples from higher in the core. Samples from the outcrop, mainly molluscs, exhibit a definite negative shift. A similar pattern is evident in $\delta^{13} \mathrm{C}$ data. Furthermore, inorganic carbonate isotope precipitation, presumably occurring in the late summer dry season, is stable, indicating groundwater predominance in these processes. Stable values for $\delta^{18} \mathrm{O}$ in inorganic carbonates also provide evidence that the variance in biogenic isotopic ratios is not caused by diagenetic alteration of carbonates.

\section{Discussion}

\section{Geochronology}

The simplest interpretation of the remanence directions observed is that the zones of consistently downward directions correspond to zones of normal $(\mathrm{N})$ polarity, whereas those of mixed reversed, intermediate, and normal polarity correspond to zones of reversed $(R)$ polarity. This interpretation leads to the magnetostratigraphy presented in Figure 3 and it is consistent with the locations of the Bishop and Huckleberry Ridge ashes in the sequence.

The difference in directional consistency between the $\mathbf{N}$ and $\mathrm{R}$ polarity zones suggests that the entire combined section has been affected by the addition of a stable, secondary, normal component. This component would be parallel to the initial normal depositional remanence (DRM; Tarling, 1983), thereby strengthening the $\mathrm{N}$ polarity. However, it would have been opposite to a reversed DRM, leading to a weakening of the $\mathrm{R}$ polarity. In some cases, the additional component has been sufficient to moderately to completely overwhelm the initial reversed DRM. This effect is most noticeable in the coarser-grained samples (sandstone, siltstone). The secondary normal component was likely acquired during the Brunhes Normal Chron. The relative strength of the secondary component indicates that it probably resides in magnetite particles. Magnetite is apparent in polished sections and in analysis of saturation magnetization versus tem- perature (principal Curie temperatures range from about $\left.560^{\circ}-580^{\circ}\right)$.

The most tentative portion of the magnetostratigraphy is associated with the Reunion Subchron, generally considered to contain from one to three separate, short, normal intervals centered at about 2.07 Ma (Mankinen and Dalrymple, 1979, Shuey et al., 1974). Two thin normal intervals are apparent in the core (Fig. 3). The Huckleberry Ridge Ash (2.02 Ma) occurs at the top of the uppermost of these two zones. We have concluded that the single $\mathrm{N}$ sample from $90 \mathrm{~m}$ depth represents a third magnetozone. Although the evidence for a third magnetozone is weak, any other interpretation results in highly anomalous sedimentation rates for this section of the core.

Except for the base of the Jaramillo, the boundaries between the principal $\mathrm{N}$ and $\mathrm{R}$ zones are located within 40 to $50 \mathrm{~cm}$ intervals in the core. The base of the Jaramillo Subchron could only be determined within $380 \mathrm{~cm}$ as a result of substantial core loss (ca. $21 \mathrm{~m}$ in Fig. 2).

\section{Sedimentation rate/hiatuses}

The average rate of sedimentation in the section between the two ashes is $6.6 \mathrm{~cm} / 1000 \mathrm{yr}$. It is $7.1 \mathrm{~cm} / 1000 \mathrm{yr}$ based on the magnetostratigraphy from the top of the Gauss to the base of the Brunhes, i.e. over nearly the entire length of the combined section. It was estimated to be $6.9 \mathrm{~cm} / 1000 \mathrm{yr}$ from surface outcrop data (Rogers et al., 1985). These calculations may seem precise for the data set; however, they are remarkably similar. In the Hansen Bluff depositional environment, erosional surfaces (e.g. the Brunhes/Matuyama boundary in the outcrop) and stable surfaces (e.g. partially formed soil horizons) apparently formed periodically. Nevertheless, over long intervals sediment accumulation was apparently limited by factors such as accommodation space provided in the basin by vertical movements across the Sangre de Cristo fault.

Within the constraints discussed above, the magnetostratigraphy provides a series of datum points within the section accurate to about $\pm 0.5 \mathrm{~m}$. Interpolation between these points and extrapolation using the average sedimentation rate to the 
top and base of the Hansen Bluff section provide dates for the total outcrop and cored section (Table 3). On this basis, sediments in the outcrop range in age from 0.86 to $0.67 \mathrm{Ma}$ (Rogers et al., 1985), whereas those in the core range from 2.60 to $0.80 \mathrm{Ma}$.

The range of sedimentation rates within paleomagnetic control points is presented in Fig. 5. The highest sedimentation rates were calculated assuming the reversal took place adjacent to the sample of opposite polarity, giving the interval its maximum sediment. Conversely, lowest sedimentation rates were calculated assuming minimum sediment within the interval (Fig. 2). Over paleomagnetic intervals, variations in sediment accumulation rate are apparent; rates are lowest before and during the Olduvai Subchron, and highest during the Jaramillo Subchron.

\section{Provenance}

The Hansen Bluff core contains sediments interpreted to have been deposited by three shifting fluvial systems - an axial stream, San Juan piedmont streams, and Sangre de Cristo piedmont streams. Deposits of the three can be distinguished on the basis of sediment composition. The provenance of the two piedmont-stream systems is lithologically distinct and the axial stream should reflect a mixing of these two sediment sources with some

TABLE 3

Correspondence between depth and age in the Hansen Bluff outcrop and in the core section. The correspondence is based on magnetostratigraphy, ash beds, interpolation between known points, and extrapolation to the top and bottom of the sequence.

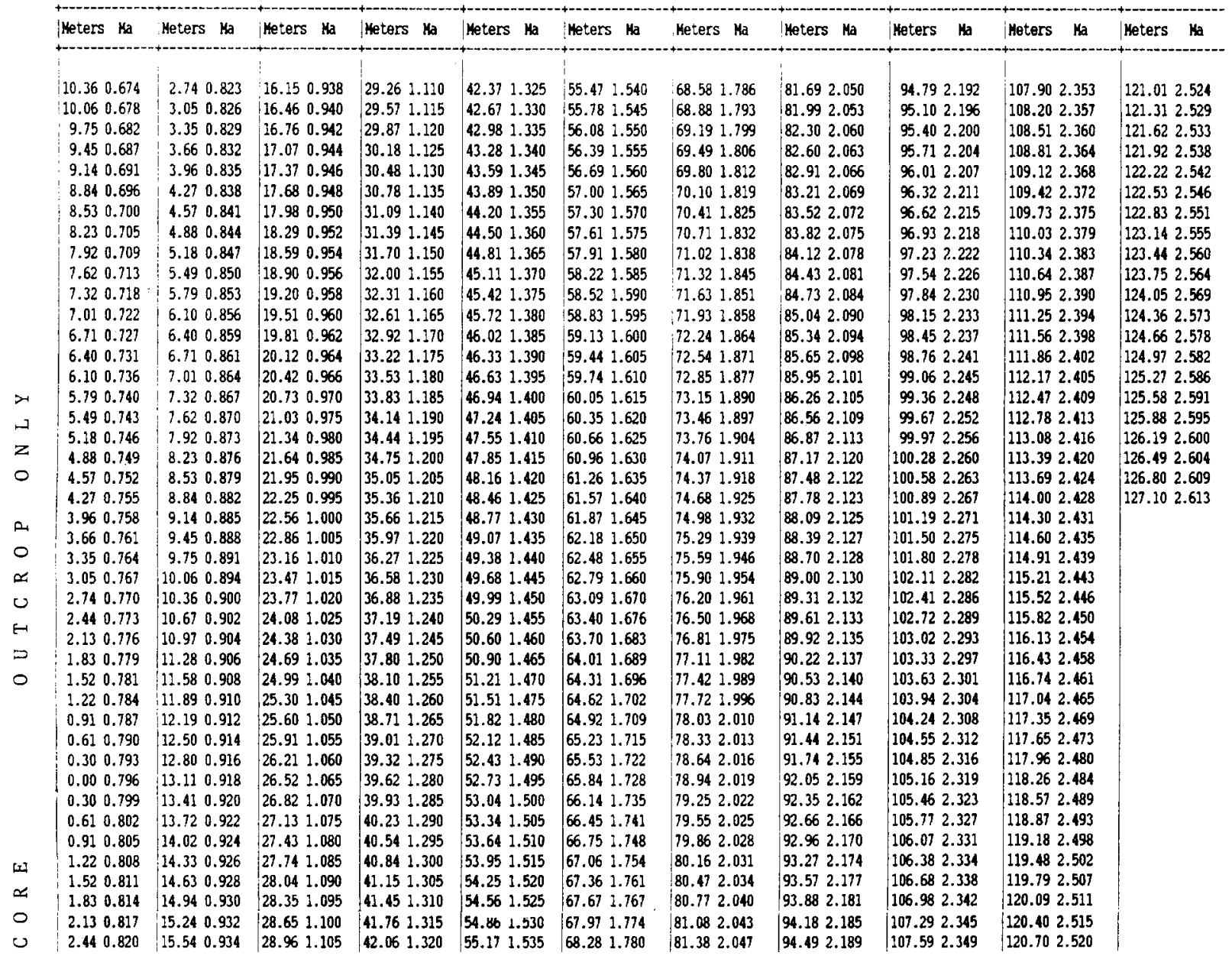


bias toward volcaniclastic material because the San Juan Mountain watersheds are larger than those in the Sangre de Cristo Mountains, and the axial stream most likely headed in the San Juan Mountains.

Restricted compositions reflecting San Juan and Sangre de Cristo sources are not represented in the core. Hansen Bluff was probably near the confluence of all three fluvial systems during the last $2.6 \mathrm{my}$ as lateral shifting of the fluvial systems and periodic flooding occurred. The sediment composition data suggest a long-term eastward migration of depositional systems within the valley (Fig. 4).

\section{Variations in sedimentation rate as a climatic} signal

Floodplain deposits are expected to represent fast sediment accumulation (Allen, 1979, Bridge and Leeder, 1979, Blakey and Gubitosa, 1984, Kraus and Middleton, 1987, Schuster and Steidtmann, 1987). Vertical aggradation of both channel and floodplain areas takes place rapidly compared to rates of channel migration, resulting in a higher proportion of floodplain facies preserved. However, during slow accumulation, channels shift laterally and remove floodplain sediments redepositing them as channel facies.

In the Hansen Bluff data, an inverse relationship exists between sedimentation rate and proportion of channel facies (Fig. 5); the highest sedimentation rates, for strata near the top of the core, correlate with the greatest abundance of floodplain deposits. A slow sediment accumulation rate, consistent with the occurrence of mainly channel deposits, characterizes the period immediately before and during the Olduvai Subchron.

Climate and/or tectonism could account for the variations in sedimentation rate observed at Hansen Bluff. The Sangre de Cristo fault, along the east edge of the San Luis Valley and bordering the Sangre de Cristo Mountains, was apparently active before, during, and after deposition of the Hansen Bluff core and outcrop sediments. Rates of movement along this fault, postdating the deposition of Alamosa Formation, are within the range of sedimentation rates calculated from Hansen Bluff.
Provenance data indicate an increasing San Juan influence upward in the sediments. During basin subsidence, eastward tilting of the San Luis Valley floor would cause an eastward shift in fluvial systems and result in the observed changes in provenance. If tectonism alone accounts for the sedimentation rate changes, then sedimentation rate in Fig. 5 reflects levels of tectonism along the Sangre de Cristo fault, ie. relatively little movement during the Olduvai Subchron, and much movement during the Jaramillo Subchron.

Alternatively, sedimentation rates at Hansen Bluff may have been controlled by sediment supply and closed-basin lake size, both of which are affected by climate-hydrologic factors. Today, water and sediment supply to the valley floor and water level in the San Luis Lakes (Fig. 14C) are controlled by run off from mountain snow during the spring; vegetation growth is enhanced during high-water years. In the Hansen Bluff record, increased rates of sediment accumulation and preservation of floodplain sediments would be favored by high water tables and increased vegetation to stabilize channels. Thus, the changes in provenance observed in the Hansen Bluff core could be a natural consequence of progradation of the San Juan piedmont. Because San Juan stream watersheds are larger than those draining the Sangre de Cristo Mountains, more sediment would be expected from them than from the piedmonts from the east.

Several observations support the hypothesis that sedimentation was controlled by climate. A 2 to 3 $\mathrm{m}$ drop, similar to Holocene Sangre de Cristo fault movements (McCalpin, 1983), at one side of a $37 \mathrm{~km}$-wide valley would have little effect on slope of the valley floor. Furthermore, much of the movement along the Sangre de Cristo fault may have caused mountain uplift rather than valley floor downdrop (McCalpin, 1983). A tectonic hypothesis would imply periods of slow sediment accumulation, e.g. before and during the Olduvai Subchron, to coincide with westward progradation of piedmont facies away from the tectonically active Sangre de Cristo basin margin. A westward shift in facies is not observed in the provenance of the sediments. The low sediment accumulation rates before and during the Olduvai Subchron 
(A)

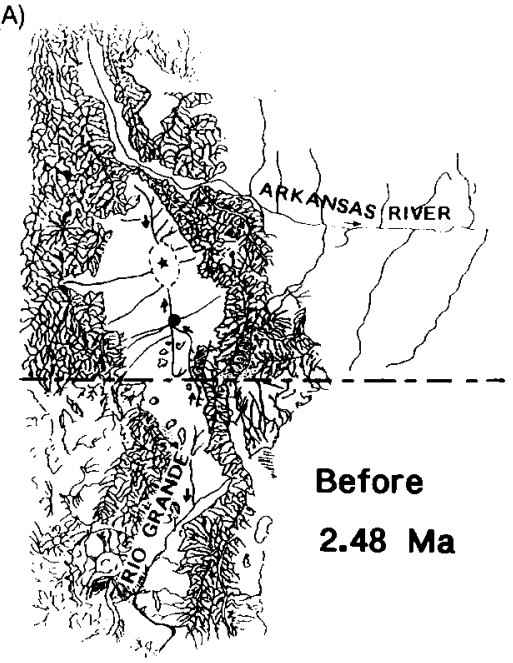

(C)

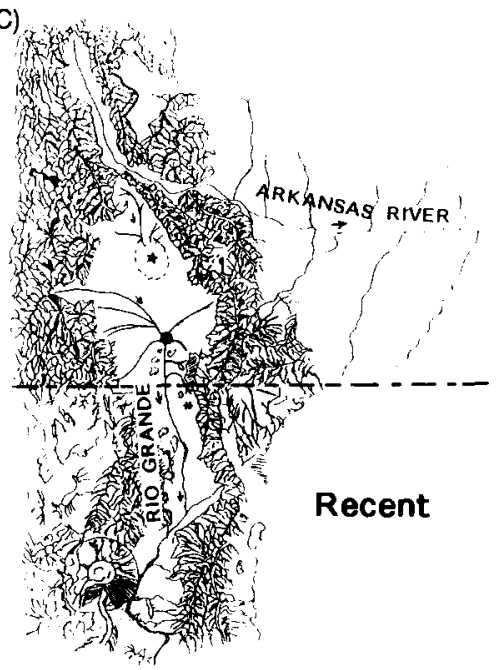

(B)
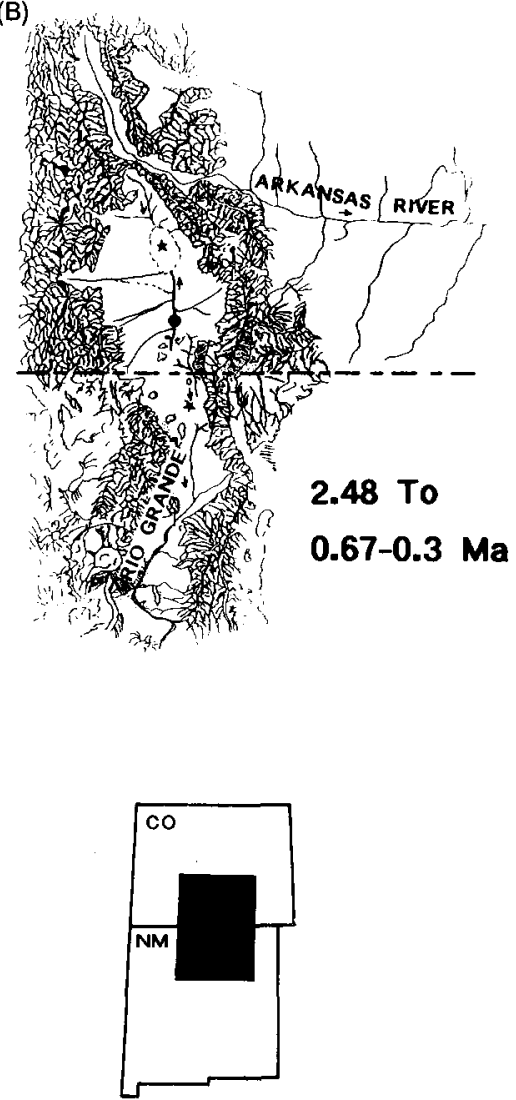

KEY:

- hANSEN BLUFF

* closed basin lake

* quaternary alluvium

Fig. 14. Stepwise integration of the San Luis Drainage Basin into the Rio Grande River. A. Gauss B. Matuyama and early Brunhes C. Recent. The closed basin lakes in the San Luis Valley today are called the San Luis Lakes. The San Luis Hills are just north of the New Mexico state line in the southern San Luis Valley.

coincide with slow sediment accumulation rates in the tectonically stable San Pedro Valley of southeastern Arizona (Lindsay et al., 1990). The coincidence of similar sedimentological changes in different basins suggests the influence of climate, rather than tectonism.

Other data from the Hansen Bluff core support climate-hydrologic control of variations in sedimentation rate. Biogenic stable-isotope data, discussed later in this paper, indicate decreasing summer precipitation on the valley-floor up-core. If the modern relationship between mountain and valley precipitation occurred in the past, then valley precipitation would have been lowest when mountain precipitation and sediment accumulation rates were highest. In the Jaramillo Subchron, sedimentation rates were highest when ostracod stable isotopes indicated that valley floor precipitation was low. Conversely, before and during the Olduvai Subchron, stable isotopes indicated relatively high summer precipitation while sedimentation rates were low. Thus, at least indirectly, stable isotope data support a climate-hydrologic control of the sedimentation rate. Therefore, if variations 
in sedimentation rate were controlled by climate, it seems probable they reflect changes in amounts of precipitation in the surrounding mountains.

\section{Fauna}

Although limited, faunal data provide observations that contribute to reconstruction of paleoclimate and paleogeography. Throughout the core, warm indicator species are more prevalent than cold indicator species. Allophaiomys sp., present at about 1.89 and $1.53 \mathrm{Ma}$, Limnocythere bradburyi and possibly its ancestral species $L$. n.sp.A (Fig. 8), indicate mild winters with few freezes. Fish identified from the core are all warm-water forms.

In contrast, $L$. ceriotuberosa, a cold climate ostracod, occurs only in restricted portions of the core at about 2.4, 2.1, 1.5, 0.91, and $0.89 \mathrm{Ma}$. This species also occurs in the outcrop during the Stage 22 glaciation and is present in the San Luis Valley today. Additionally, cutthroat trout, Onchorhynchus clarki, which now thrive in cool mountain streams, are absent in the core. There is evidence that these trout were widespread in western North America during the Pliocene (Stearly and Smith, in prep.), although there is no evidence they had reached the San Luis Valley by that time. They appear by $0.74 \mathrm{Ma}$ at Hansen Bluff, and become common in the upper part of the section. Absence of trout in the many fish-rich parts of the core is an indication that temperatures were at least as warm as in parts of the lower San Luis Valley today.

Dry climate species include an ostracod and a lizard. Candona patzcuaro indicates seasonal desiccation when it is the only ostracod present; this occurs at around $2.1,1.8,1.6,1.5$, and $1.0 \mathrm{Ma}$. The lizard, Phrynosoma douglassi, lives in dry San Luis Valley grasslands and occurs at about 0.94 $\mathrm{Ma}$ in the Hansen Bluff core.

Wet indicator species include the ostracod, Limnocythere platyforma, and the rodents, Allophaiomys and Reithrodontomys. The ostracod is thought to be indicative of water freshening, either by precipitation or by diversion of a new water source into the lacustrine environment. It occurs at around 2.4, 2.3, 1.60, 1.57, 1.3, and $0.91 \mathrm{Ma}$; these occurrences do not coincide with provenance changes and probably reflect precipitation changes.
The fossil distribution of Allophaiomys (at about 1.89 and $1.53 \mathrm{Ma}$ at Hansen Bluff) indicates a preference for areas with relatively high rainfall and frequent cloudy summer days (Repenning, 1990). Reithrodontomys, (at about $1.53 \mathrm{Ma}$ at Hansen Bluff) is particularly abundant in wet areas.

Species of clams and snails apparently occur in the sedimentary record when water tables were high; they indicate perennial, well-oxygenated water and were present at about 2.16, 1.83, 1.60, and $0.83-0.84 \mathrm{Ma}$. The most likely source of perennial, well-oxygenated water on the San Luis Valley floor is from relatively high mountain runoff.

\section{Pollen}

The interpretation of the pollen sequence is not completely straightforward. Many pollen sites from small, high-elevation lakes in the Rocky Mountains record climate changes during the last glaciation and the Holocene. These sites show that high Artemisia and relatively low Pinus pollen percentages are characteristic of cold glacial conditions, and the reverse indicates warm Holocene climates (Baker, 1976, 1983; Barnosky et al., 1987. Legg and Baker, 1980, Wright et al., 1973). At lower elevation sites, some at or below lower treeline, Pinus pollen is most abundant during cooler times, and Artemisia and other NAP (nonarboreal pollen) become dominant during the Holocene, continuing to the present (Bright, 1966; Markgraf and Scott, 1981; Markgraf and Lennon, 1986). Surface samples also show that sites in many of the large, open basins of the Rocky Mountain region are dominated by Artemisia, Poaceae, Chenopodiineae, Sarcobatus, and Ambrosia pollen, and the prevailing pollen rain in the mountains is Pinus, along with Picea and Abies (Hall, 1990; Maher, 1963; McAndrews and Wright, 1969).

The large size and high altitude of the San Luis Valley and the lake occupying the northern portion of the valley mandate extra care in interpreting the pollen sequence. The high altitude of the basin means it could react like other high-altitude sites in the Rocky Mountains, or like other large basins. That is, the high Pinus and low Artemisia percent- 
ages could mean cold or warm conditions. Holocene cores (Jodry et al., 1989), the other biological indicators, and a surface pollen sample in the San Luis Valley (Fig. 10) help to resolve this problem. In the Hansen Bluff outcrop, several other biotic indicators showed that periods rich in Pinus pollen occur during cool, wet periods, when treeline descended and the valley floor supported pines. High percentages of Artemisia and other taxa indicated warm, dry periods, with the treeline above the basin floor. When several other NAP elements were high, as they are now, conditions were warmest and driest, allowing warm-steppe elements to dominate (Rogers et al., 1985).

With the interpretation of the outcrop samples as a model, the core portion of the sequence appears to represent most of a cold-warm (possibly glacial-interglacial) cycle. The high pine percentages near the top of the core would indicate relatively cold, wet conditions. The NAP elements in the middle of the pollen sequence from the core suggest that conditions were warm and dry, and interglacial conditions prevailed. The high pine percentages near the base of the pollen samples suggest a return to cold, wet conditions.

These interpretations are based on the assumption that a site receives pollen that represents the surrounding area. In large lakes with large drainage basins, much of the pollen can be derived from inflow of rivers (Jacobson and Bradshaw, 1985; Maher, 1977; McAndrews and Power, 1973). If changes in drainage into the basin occur, then pollen shifts can be non-climatic in origin. Several observations support a climatic origin of pollen shifts in the Hansen Bluff sequence.

Sedimentologically, this interval at Hansen Bluff represents flood basin ponds and marshes associated with San Juan piedmont streams; no changes in river inflow are apparent. Further, ostracod faunal composition supports the climatic fluctuation, although the associated data do not indicate cold periods as extreme as the Stage 22 glaciation. Thus, drainage shifts probably did not cause pollen fluctuations.

\section{Geochemistry}

If the inorganic isotope data were the only data available, the following climatic interpretation could not be made; past $\mathrm{CO}_{2}$ concentrations in the atmosphere could affect the plant limiting factors upon which the inferences are drawn. The interpretation depends upon whether $\% \mathrm{C} 4$ plants determined from the inorganic $\delta^{13} \mathrm{C}$ data were due primarily to $\mathrm{C} 4$ grasses or $\mathrm{C} 4$ dicots.

If plants contributing to the vadose carbonate were mainly grasses, then, percentage of $\mathrm{C} 4$ plants correlates with July minimum temperature (Teeri and Stowe, 1976). If the C4 plants are mainly grasses and if modern grass/climate relationships were consistent during past $P\left(\mathrm{CO}_{2}\right)$ concentrations, then minimum temperatures during the growing season at Hansen Bluff were substantially warmer than today and became progressively warmer from 2.6 to $0.93 \mathrm{Ma}$ (Fig. 12). Normal July minimum temperature in the center of the San Luis Valley at present is $8.9^{\circ} \mathrm{C}$, which would predict only $10 \%$ of native grasses to be $\mathrm{C} 4$ (Teeri and Stowe, 1976).

Alternatively, if the percentages of $\mathrm{C} 4$ plants deduced from the Hansen Bluff vadose carbonates were primarily $\mathrm{C} 4$ dicots, then the more positive $\delta^{13} \mathrm{C}$ values indicate increasing mean summer (May-October) pan evaporation up-core. Today, with $192 \mathrm{~cm} / \mathrm{summer}$ pan evaporation (Doesken, pers. comm., 1991), 1.7\% dicot species (Stowe and Teeri, 1978) would be expected in the San Luis Valley.

At present, grasses make up $50 \%$ or more of the biomass on San Luis Valley floodplains; during wet years, other monocots (eg. sedges, many of which are $\mathrm{C} 4$ ) become more prevalent (Dixon, oral comm., 1991). Therefore, estimates of climatic change at Hansen Bluff from vadose $\delta^{13} \mathrm{C}$ data based primarily on $\mathrm{C} 4$ grasses are probably more accurate than estimates based on $\mathrm{C} 4$ dicots. Nevertheless, if summer temperature actually did increase, it would also increase summer pan evaporation (Doesken, pers. comm., 1991), making the area more habitable for $\mathrm{C} 4$ dicots.

In summary, the $\% \mathrm{C} 4$ species contributing to the vadose carbonate-isotope data suggest a trend toward warmer summer temperatures and higher summer pan evaporation from before $2.48 \mathrm{Ma}$ to about $0.93 \mathrm{Ma}$ at Hansen Bluff.

In the following interpretation of biogenic isotope data, we assume that surface fresh-water 
A

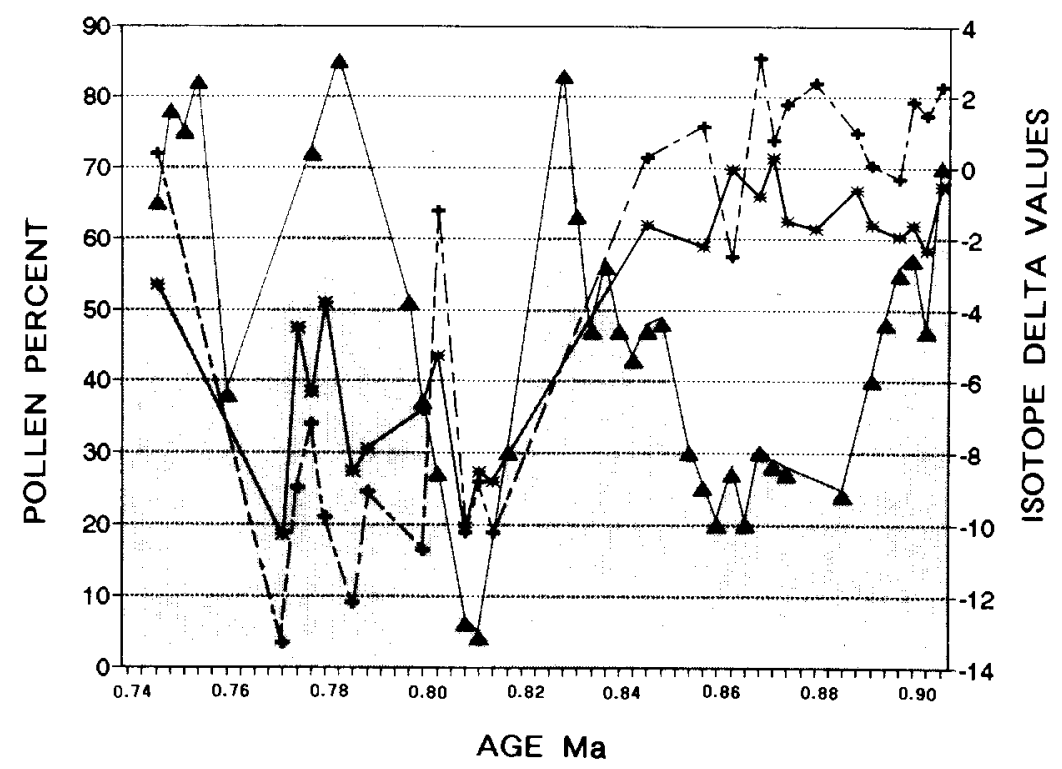

$\square$ PINUS POLLEN

* DELTA 18 OXYGEN

+ DELTA 13 CARBON

B

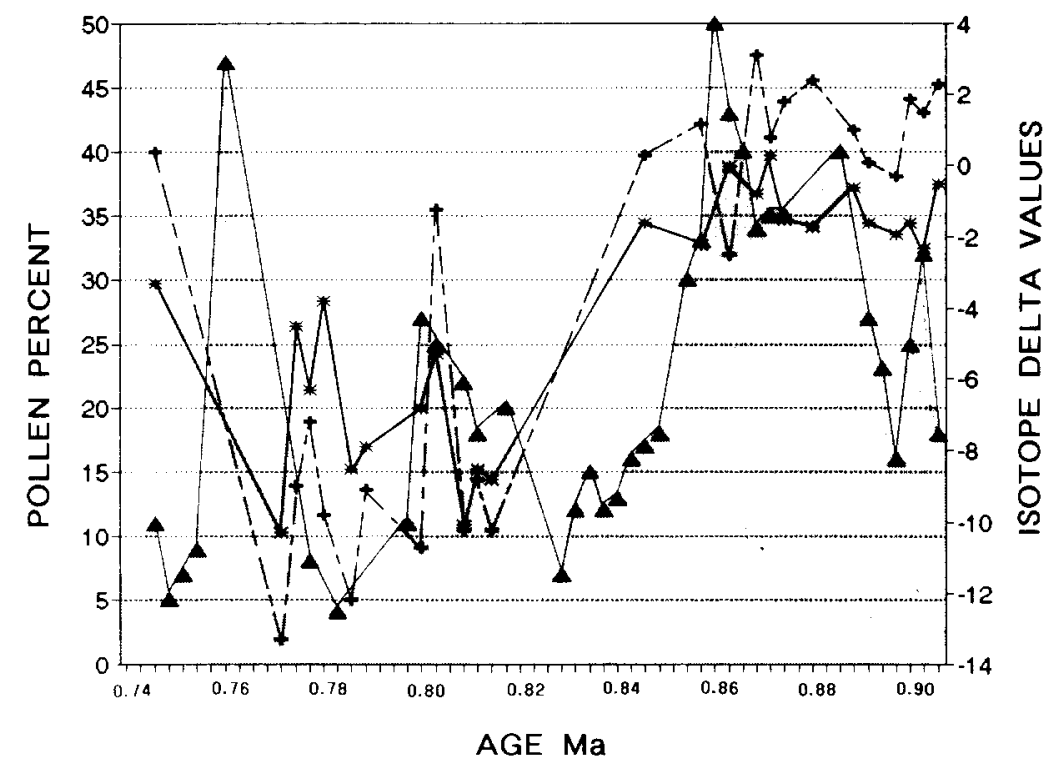

1. ARTEMISIA POLLEN

* DELTA 18 OXYGEN

+ DELTA 13 CARBON

Fig. 15. Pollen percentages plotted with biogenic stable-isotope data. A. Pinus pollen B. Artimesia pollen 
inflow during the growing season leads to formation of biogenic carbonate depleted (more negative $\delta^{18} \mathrm{O}$ ) in ${ }^{18} \mathrm{O}$ and that progressive evaporation during summer months results in ${ }^{18} \mathrm{O}$ enrichment (more positive $\delta^{18} \mathrm{O}$ ) of shallow lacustrine waters by as much as $+16 \%$ (Detman, pers. commun., 1991, Fontes et al., 1970, Gonfiantini et al, 1973). However, this positive $\delta^{18} \mathrm{O}$ shift in water composition would be attenuated in precipitated carbonate by higher temperature of crystallization. Variation in $\delta^{18} \mathrm{O}$ in biogenic carbonates is considered to have been recording mainly first order changes in the $\delta^{18} \mathrm{O}$ of lake water.

Therefore, the relatively depleted ${ }^{18} \mathrm{O}$ biogenic carbonate in the lower part of the core may indicate frequent precipitation on floodplain lakes (Fig. 13A; Table 2). If the relative abundance of depleted $\delta^{18} \mathrm{O}$ samples from before about $1.4 \mathrm{Ma}$ indicates influence of precipitation, then loss of that effect in younger sediments indicates a major reduction in rainfall or runoff during the growing season. In the outcrop samples, the effect of precipitation is apparent, and evaporative effects seem less pronounced. Thus, the data suggest increasing dominance and stability of summer evaporation relative to rainfall or runoff from about $2.4 \mathrm{Ma}$ to about $0.85 \mathrm{Ma}$ at Hansen Bluff, then decreased evaporation and increased precipitation during the Stage 22 glaciation.

During the interval between about 1.4 and 1.7 $\mathrm{Ma}$, a cluster of more positive $\delta^{18} \mathrm{O}$ values indicating evaporation are interspersed with negative values indicating precipitation. This combination indicates a transition to lower runoff and more arid summer conditions in summer after about 1.4 Ma.

We assume the major controls on carbon isotopic ratios in ostracods are local productivity (photosynthesis concentrates ${ }^{12} \mathrm{C}$ in plant tissues) and either influx of detrital organic material and its mobilization by decomposers, or the influx of soil-gas bicarbonate from groundwater. Each of these would be reflected in negative $\delta^{13} \mathrm{C}$ values for dissolved carbonate available for ostracod shell growth.

The general pattern of $\delta^{13} \mathrm{C}$ data from ostracods and molluscs is similar to that seen in $\delta^{18} \mathrm{O}$ data (compare Fig. 13A,B). The decrease, upward through the core, in negative $\delta^{13} \mathrm{C}$ values may indicate reduced input from dissolved organic carbon in surface water. Reduced decomposer activity would also lessen release of dissolved organics depleted in ${ }^{13} \mathrm{C}$. The two ancient, slightly negative clusters, at about 2.4 and $1.5 \mathrm{Ma}$, may indicate waters somewhat depleted in ${ }^{13} \mathrm{C}$ by a slight increase in recycling of terrestrial sources of organic material. The extremely depleted outcrop samples, at about 0.85 to $0.67 \mathrm{Ma}$, may indicate exceptionally heavy surface run-off.

The distribution of two ostracod species, Limnocythere platyforma and Candona patzcuaro, would be expected to reflect the hydrological changes inferred from the biogenic isotope data. In the Hansen Bluff core, ostracod carbonate has a mean $\delta^{18} \mathrm{O}$ of -5.96 (ranging from -14 to -0.05 ) when L. platyforma is present and a mean $\delta^{18} \mathrm{O}$ of -4.87 (ranging from -11 to +1.9 ) when $L$. platyforma is absent. Though these differences are not statistically significant, $L$. platyforma at Hansen Bluff tends to occur with a stable oxygen isotope record slightly depleted in ${ }^{18} \mathrm{O}$. Ranges of values overlap, however, indicating environmental factors in addition to freshening are important in the occurrence of $L$. platyforma.

Non-significant differences in biogenic isotope data also occur with $C$. patzcuaro. When other species are present with $C$. patzcuaro, $\delta^{18} \mathrm{O}$ values average nearly $2 \%$ lighter. Thus, when $C$. patzcuaro occurred alone, the water may have been more ephemeral.

Fluctuations in pollen coupled with $\delta^{18} \mathrm{O}$ and $\delta^{13} \mathrm{C}$ data provides insight into the climatic changes apparent between about 0.91 and 0.74 $\mathrm{Ma}$. In general, $\delta^{18} \mathrm{O}$ values tend to be most negative during the Stage 22 glaciation, especially between $0.82-0.74 \mathrm{Ma}$ but remain relatively positive before about $0.85 \mathrm{Ma}$. Depleted ${ }^{18} \mathrm{O}$ tends to occur with high Pinus and enriched ${ }^{18} \mathrm{O}$ tends to occur with high Artemisia, although there appears to be an offset between the two systems (Fig. 15 $\mathrm{A}, \mathrm{B}$ ). The best correspondence between pollen and isotope data can be seen between $\delta^{13} \mathrm{C}$ values and Artemisia pollen (Fig. 15B). Possibly, increased precipitation and surface runoff were important in the establishment of forests on the San Luis Valley floor but evaporative intervals with decreased sur- 
face runoff coincided with the spread of sagegrassland. No explanation for the offset is apparent.

No biogenic isotope data are available during the Pinus pollen peak centered at about $0.82 \mathrm{Ma}$. This peak and the one centered at about $0.91 \mathrm{Ma}$ are not coupled with high Picea percentages, northern faunal elements, or other indicators of glacial conditions. Because these two Pinus peaks were identified from core samples only, it may be that other indicators of glacial conditions exist in those intervals but were not recovered. However, ostracod data that occur with the 0.91 Ma Pinus peak indicate moderately cool conditions with freshening of the water body. Shortly after the peak, Limnocythere bradburyi and L. ceriotuberosa occur together indicating the presence of a permanent lake with the deep center buffered from cold winter temperatures, and colder littoral or sublittoral zones. In summary, these two Pinus peaks represent cold, wet periods, but there is no evidence to indicate they were as cold as the Stage 22 glaciation.

\section{Conclusions}

\section{Evolution of the drainage}

During most of the early Quaternary, the axial stream in the San Luis Valley probably flowed north because the basin was apparently closed and internally drained. The Rio Grande originates in the San Juan Mountains (i.e. Rio Grande Basin in Colorado) today and flows through the San Luis Valley. According to Wells et al. (1987), the northern drainage did not integrate into the ancestral Rio Grande until between $0.69 \mathrm{Ma}$ and $0.3 \mathrm{Ma}$. Evidence from the Hansen Bluff outcrop (Rogers et al., 1985) indicates that at least minor headwater-stream capture occurred between the San Luis Basin and the Taos Plateau as early as $0.82 \mathrm{Ma}$. For example, the freshwater minnow, Dionda, which occurs in the southern Rio Grande drainage today, is present in the Alamosa Formation at that time. The presence of minnows (Gila) and suckers (Catostomus) from the Rio Grande drainage in New Mexico indicates that additional headwater stream capture had occurred between the fluvial systems at about $2.4 \mathrm{Ma}$. Nevertheless, Wells et al. (1987) present strong evidence that the San Luis Valley did not drain into the Rio Grande until after the youngest Alamosa Formation sediments were deposited $(0.67 \mathrm{Ma})$.

Integration of the San Luis Basin into the Rio Grande drainage may have been stepwise and, possibly, a result of regional uplift in the northern Rio Grande rift (Bachman and Mehnert, 1978, Dethier and Demsey, 1984). Initially, a small drainage basin in the southeast corner of the valley, between Guadalupe Mountain and the San Luis Hills (Winograd, 1959, Wells et al., 1987), was probably captured (Fig. 14A). This water may have drained into a small closed-basin lake or playa north of Guadalupe Mountain; lake-playa sediments are known to occur there (Winograd, 1959). Also, Quaternary alluvium is present in New Mexico where streams from the southeast corner of the valley would have flowed (Wells et al., 1987). See Fig. 14C. One possible explanation for provenance data of Gauss-aged sediments (2.48 Ma and older) with high Sangre de Cristo influence, is that capture of the small basin did not occur until after the Gauss Chron (2.48 Ma). Such a capture would have reduced Sangre de Cristo sediment in the water as it moved past the Hansen Bluff area toward the San Luis Lakes area (Fig. 14A).

During the Matuyama Chron (2.48-0.74 Ma), the San Luis Valley apparently continued to be a closed drainage basin (Fig. 14B). Sediment at Hansen Bluff had a progressively larger influence from the San Juan Mountains, reflecting progradation of the San Juan piedmont, possibly due to the greater area of that watershed. After $0.69 \mathrm{Ma}$ when sedimentation ceased at Hansen Bluff, but before 0.3 Ma (Wells et al., 1987), capture of streams through the San Luis Hills diverted much of the San Luis Valley drainage into the Rio Grande, although the area around the San Luis Lakes remained a small closed basin (Fig. 14C).

Various authors have hypothesized stream-flow from the Upper Arkansas graben north of the San Luis Valley into the San Luis Basin began in the late Oligocene/early Miocene and continued into the late Pliocene/early Pleistocene (Van Alstine, 
1968, 1970; Knepper and Marrs, 1971; Hanna and Harmon, 1989). Evidence for this paleodrainage was the presence of the Mio-Pliocene Dry Union Formation on Poncha Pass at the north end of the San Luis Valley. However, Brister and Gries (in press) report that neither surface mapping nor gravity surveys indicate significant Dry Union/ Santa Fe deposits at Poncha Pass; instead a topographic and/or structural barrier existed at Poncha Pass during the Miocene and Pliocene. Additionally, freshwater fish present in outcrop and core sediments at Hansen Bluff are not closely related to Arkansas River fish. However, trout are present in Alamosa Formation sediments above the base of the Brunhes $(0.74 \mathrm{Ma})$ (Rogers, et al., 1985). Trout originated on the Pacific coast and most likely entered the San Luis Valley through headwater stream capture from the Arkansas River; see Fig. 14 for proximity of the drainages.

Thus, the general paleogeography of the central and southern San Luis Valley during the late Pliocene and early Pleistocene probably consisted of a closed-basin axial drainage, which flowed NNE toward the San Luis Lakes and was flanked by piedmont streams and fans. The presence of the closed basin lakes is supported by nearly 610 $\mathrm{m}$ of lake clays in the Mapco-Amoco well near the San Luis Lakes (Burroughs, 1981).

\section{Climatic reconstruction}

Several broad trends in climate are evident from the Hansen Bluff core data. Most of the core section apparently represents a time that was warmer than conditions in the San Luis Valley today. Vadose $\delta^{13} \mathrm{C}$ data indicate warm temperatures for growth of $\mathrm{C} 4$ plants. Ostracods include Limnocythere bradburyi, a species living only south of the frostline in the United States today. Three warm-water species of fish that occur in New Mexico and Mexico today are present and coldwater trout are absent. The fossil microtine, referred to Allophaiomys, a rodent species indicative of warm periods is present. From these data, it is apparent that minimum growing-season temperatures were significantly higher than at present (possibly by as much as $4-7^{\circ} \mathrm{C}$ ); the time represented in the core above the Olduvai was warmer yet by $1-3^{\circ} \mathrm{C}$. Such warming would cause mean annual temperature to rise about $3-5^{\circ} \mathrm{C}$ from present day, making the temperatures at that time similar to those recorded just south of Albuquerque in New Mexico today (Doesken, pers. comm., 1991).

Several lines of evidence indicate a shift in climate at about the end of the Olduvai (at about $1.6 \mathrm{Ma}$ ). Changes in biogenic $\delta^{18} \mathrm{O}$ and $\delta^{13} \mathrm{C}$ values, sedimentation rate, and ostracod faunal composition indicate that the lower part of the core primarily represents a time of abundant summer precipitation on the San Luis Valley floor. If the modern relationship between the mountain and valley floor precipitation occurred in the past, mountain precipitation during the Olduvai would have been less than in the upper part of the core. May-October pan evaporation rates appear to have been considerably less and terrestrial productivity was probably higher than occurred during deposition of the upper half of the core.

After the Olduvai event, the San Luis Valley went through a period of transition lasting a maximum of 200,000 years. Mountain precipitation, valley-floor summer precipitation, MayOctober pan evaporation, terrestrial productivity and temperatures oscillated between high and low values. The transitional period included oscillating $\delta^{18} \mathrm{O}$ and $\delta^{13} \mathrm{C}$ values and repeated faunal changes.

A short period during the middle Reunion event is characterized by low valley and high mountain precipitation, heavy summer evaporation with corresponding low terrestrial productivity, and a high sedimentation rate. This reconstruction is based on the presence of Candona patzcuaro occurring without other species, an indicator of seasonal desiccation of ponds, and also on biogenic $\delta^{18} \mathrm{O}$ values with several high positive peaks and on $\delta^{13} \mathrm{C}$ values that form a cluster of positive data points.

Toward the top of the core and in the base of the outcrop sediments, there is evidence that the climate began to oscillate between the earlier warm conditions and conditions similar to, but not as severe as, the Stage 22 glacial conditions recorded in the outcrop. Pollen, biogenic isotope values, and ostracod faunal composition vary between 


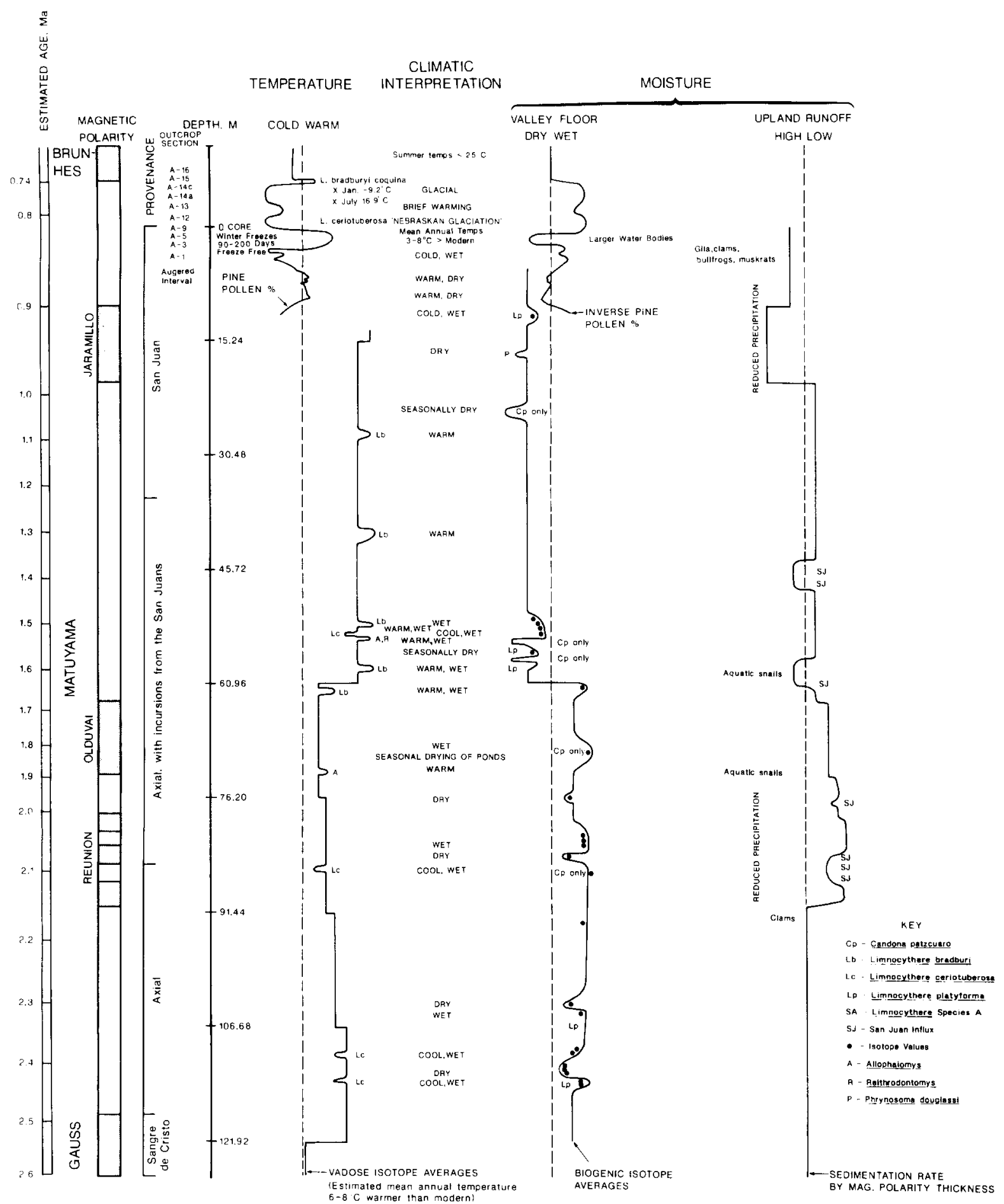

Fig. 16. Synopsis of climate data including selected outcrop data that was published in Rogers et al. (1985). Straight lines represent means over $15.25 \mathrm{~m}$ ( 50 -foot) intervals; curved lines represent deviations from the means. Dashed vertical lines indicate modern temperature and moisture values (See Table 1). 


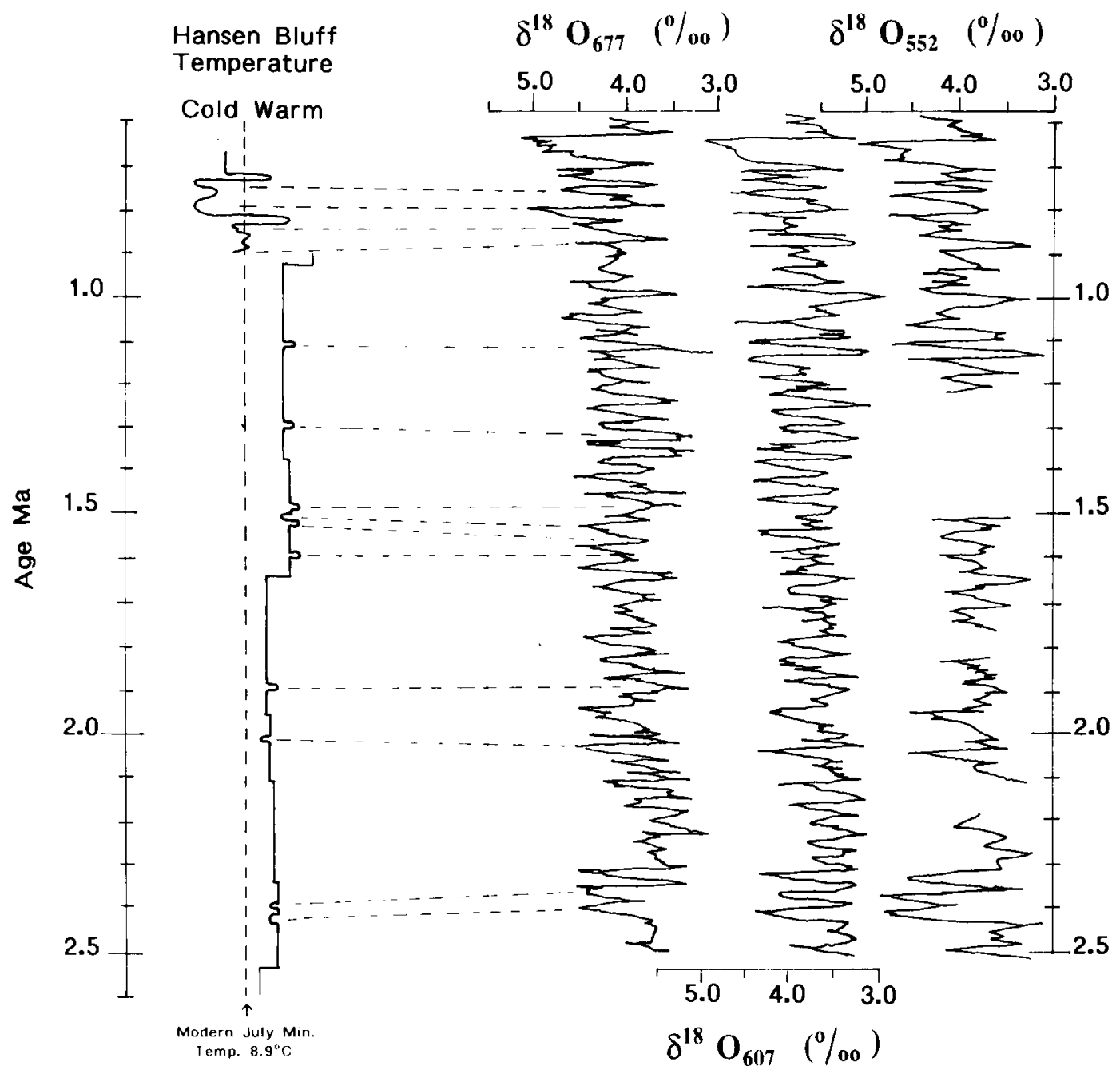

Fig. 17. Parallels between the deep sea oxygen isotope temperature record and the Hansen Bluff temperature record. The general temperature trends are similar as well as detailed oscillations.

warm/cool, wet/dry, and more/less surface run off conditions.

Cool periods are recorded by the ostracod, Limnocythere ceriotuberosa, and by the presence of pine forest vegetation on the San Luis Valley floor. Using these criteria, several cool periods are apparent at about 2.35-2.43, 2.10, 1.5, 0.91, 0.89, and $0.84-0.82$, in addition to the Stage 22 glaciation between about $0.80-0.74 \mathrm{Ma}$.

All data pertaining to climate at Hansen Bluff are summarized in Fig. 16. Baseline mean values, corresponding to $15.25 \mathrm{~m}$ long core segments were plotted. Deviations from the mean by outlying data points or faunal evidence were added. Data are shown for temperature, valley precipitation/ evaporation, and mountain precipitation. Overall climatic interpretations are provided wherever possible.

The temperature summary from Fig. 16 redrawn to a uniform time scale is presented in Fig. 17, along with several deep-sea oxygen isotope records spanning the interval represented at Hansen Bluff. The time represented in the core section corresponds to oxygen-isotope stages 110 through 23, at North Atlantic sites 607 and 609 (Raymo et al., 1989; Ruddiman et al., 1986; Ruddiman et al., 1989). Even in the upper section of the core, where a pollen record is available, correlation below stage 
23 is highly speculative and has not been attempted. Nevertheless, correspondences between warm and cold oscillations can be made between the two sequences. Further, relatively warm, stable climates evident in the deep sea data during the Matuyama are reflected in the Hansen Bluff data. Therefore, it is apparent the climatic history present in Alamosa Formation sediments reflects global changes in the climate system.

\section{Summary}

The Hansen Bluff combined core and outcrop section represents nearly continuous sedimentation from about 2.67 to $0.67 \mathrm{Ma}$. The sediments include all magnetic chrons and subchrons expected during that interval.

During and after deposition of the upper part of the Alamosa Formation, the San Luis Basin was integrated into the Rio Grande drainage. This occurred in a stepwise fashion and left a small area of the San Luis Valley as an internally drained basin.

From 2.67 to about $0.93 \mathrm{Ma}$, mean annual temperature in the San Luis Valley was significantly warmer (by $3-5^{\circ} \mathrm{C}$ ) than today. Most interglacial events were similarly warm.

An important change in climate began at the top of the Olduvai, and lasted for about 200,000 yrs. During this time, there was a decrease in summer rain, an increase in summer pan evaporation, an increase in mountain precipitation, and higher summer temperatures.

The general pattern of climate and some of the climatic oscillations present in the deep sea record are apparent in the Hansen Bluff data. This indicates that the Hansen Bluff climatic record reflects global changes.

\section{Acknowledgments}

We thank two anonymous reviewers whose comments substantially improved the manuscript. J. P. Bradbury, R. Forester (USGS, Denver), and V. Markgraf (Inst. Arctic Alp. Res.) provided many suggestions, fossil identification, and frequent council during the coring and core study, and their help has been deeply appreciated. Those who have identified fossils or have been otherwise involved in various aspects of this study include $E$. Anderson (Denver), T. Brown (Univ. Wisconsin), S. Hall (Univ. Texas, Austin), G. Izett (USGS, Denver), R. Thompson (USGS, Denver), D. Schwert (N. Dak. St. Univ.), R. Gries (Denver), B. Brister (New Mex. Bur. Mines Min. Res.), T. VanDevender (Sonoran Desert Mus.), N. Doesken (Colo. Clim. Cent.), and D. Taylor (Tiburon Cent.). Faculty and staff at Adams State College have given their assistance generously, especially $\mathrm{H}$. Dixon, D. Burroughs, R. Peterson, D. Stewart, P. McGee, R. Loser, E. Adams, B. Moeney, J. Reed, K. Vest, M. Cousineau, S. Sedlachek, and M. Vohs. M. Nail of the Alamosa Wildlife Refuge was most cooperative in providing permission for access onto protected land. We thank J. Zachos, J. Burdette, D. Detman, and B. Patterson for various aspects of ostracod isotope analysis and for discussions that led to a clearer understanding of the meaning of the data. Student help at several institutions was essential to many labor-intensive aspects of the study. We thank K Schiel (Univ. New Mex.) for petrographic modal analyses of sandstones, L. Schultz (Univ. Iowa) for running pollen samples, and numerous dedicated science students (including J. Bini, S. Hendricks, D. Foiles, K. Weaver, S. Hokensen, N. Martin, M. Martin, C. Mitchel, L. Harvey, A. Rogers, M. Romano) at Adams State College for sampling, washing, picking, and other work related to the study. Drillers from Boyles Brothers Drilling went above and beyond the call of duty to recover core under extremely difficult conditions. Funding from the National Geographic Society (grant number 3335-86), and National Science Foundation (grant number ATM-8912517) is also gratefully acknowledged.

\section{References}

Allen, J.R.L., 1979. Studies in fluviatile sedimentation: An elementary geometrical model for the connectedness of avulsion-related channel sand bodies. Sediment. Geol. 24 253-267.

Bachman, G.O. and Mehnert, H.H. 1978. New K-Ar dates and the late Pliocene to Holocene geomorphic history of the central Rio Grande region, New Mexico. Geol. Soc. Am Bull., 89: 283-292.

Baker, R.G., 1976. Late Quaternary vegetation history of the 
Yellowstone Lake Basin, Wyoming. U.S. Geol. Surv. Prof. Pap., 729-E.

Baker, R.G., 1983. Holocene vegetational history of the western United States. In: H.E. Wright Jr., (Editor), Late-Quaternary environments of the United States, Volume 2, The Holocene. Univ, Minn. Press, Minneapolis, pp. 109-127.

Barnosky, C.W., Anderson, P.M. and P.J. Bartlein. 1987. The northwestern U.S. during deglaciation; vegetational history and paleoclimatic implications. In: W.F. Ruddiman, and H.E. Wright Jr., (Editors), Geology of North America, Vol. K-3. North America and Adjacent Oceans during the last deglaciation. Geol. Soc. Am., Boulder, Colorado, pp. $289-322$.

Berner, R.A. 1990. Atmospheric carbon dioxide levels over Phanerozoic time. Science 249: 1382-1386.

Birkland, P.W. 1984. Soils and geomorphology. Oxford Univ. Press, New York, 372 pp.

Blakey, R.C. and Gubitosa, R, 1984. Controls of sandstone body geometry and architecture in the Chinle Formation (Upper Triassic), Colorado Plateau. Sediment. Geol. 38: $51-86$.

Bodrig, P.D. 1989. An overview of a water budget for the San Luis Valley, Colorado. In: E.J. Harmon, (Editor), Water in the valley; A 1989 perspective on water supplies, issues and solutions in the San Luis Valley, Colorado. Colo. Groundwater Assoc., 1989. pp. 73-78.

Bridge, J.S. and Leeder, M.R., 1979. A simulation model of alluvial stratigraphy. Sedimentology, 26: 617-644.

Bright, R.C., 1966. Pollen and seed stratigraphy of Swan Lake, southeastern Idaho: Its relation to regional vegetational history and to Lake Bonneville history. Tebiwa, 9: 1-47.

Brister, B.S. and Gries, R.R., in press. Tertiary stratigraphy and tectonic development of the Alamosa Basin, Rio Grande Rift, South-central Colorado, $57 \mathrm{pp}$.

Burroughs, R.L., 1981. A summary of the geology of the San Luis Basin, Colorado-New Mexico with emphasis on the geothermal potential for the Monte Vista Graben. Colo. Geol. Surv., Spec. Pubbl., 17: 1-30.

Cerling, T.E., 1984. The stable isotopic composition of modern soil carbonate and its relationship to climate. Earth Planet. Sci. Lett., 71: 229-240.

Cerling, T.E., Quade, J., Wang, Y., and Bowman, J.R. 1989. Carbon isotopes in soils and paleosols as ecology and paleoecology indicators. Nature, 341(6238): 138-139.

Chapin, C.E., 1971. The Rio Grande rift; Part I, modifications and additions. In: New Mex. Geol. Soc. Guidebook of the San Luis Basin, 22nd Field Conf., pp. 191-201.

Chapin, C.E., 1979. Evolution of the Rio Grande rift, a summary. In: R.E. Riecker, (Editor), Rio Grande rift: tectonics and magmatism. AGU, Washington, D.C., pp. 1-5.

Chapin, C.E., 1988. Axial basins of the northern and central Rio Grande rift. In: L.L. Sloss, (Editor), Sedimentary cover, North American craton. Geol. Soc. Am., pp. 165-170.

Cordell, L., 1978. Regional geophysical setting of the Rio Grande rift. Geol. Soc. Am. Bull., 89: 1073-1090.

Deines, P. 1980. The Terrestrial Environment. In: Handbook of Environmental Isotope Geochemistry, 1. The Terrestrial Environment. Elsevier, Amsterdam, pp. 329-406.

Delorme, L.D. and Donald, D., 1969. Torpidity of freshwater ostracodes. Can. J. of Zool, 47(5): 997-999.
Dethier, D.P. and Demsey, K.A., 1984. Erosional history and soil development on Quaternary surfaces, northwest Espanola Basin, New Mexico. In: New Mex. Geol. Soc. Guidebook, 35th Field Conf., pp. 227-233.

Doesken, N.J. and McKee, T.B., 1989. The incredible climate of the San Luis Valley. In: E.J. Harmon (Editor), Water in the valley; A 1989 perspective on water supplies, issues and solutions in the San Luis Valley, Colorado. Colo. Groundwater Assoc. 1989, pp. 80-98.

Downton, W.J.S., 1975. The occurrence of C4 photosynthesis among plants. Photosynthetica, 9: 96-105.

Emery, P.A. 1971. Water Resources of the San Luis Valley, Colorado. In: New Mex. Geol. Soc. Guidebook of the San Luis Basin, 22nd Field Conf., pp. 129-132.

Fontes, J.C., Gonfiantini, R. and Roche, M.A, 1970. Deuterium et oxygene-18 dans les eaux du lac Tchad. In: Isotope Hydrology 1970. IAEA, Vienna, pp. 387-404.

Forester, R.M., 1985. Limnocythere bradburyi n. sp.: A modern ostracode from central Mexico and a possible Quaternary paleoclimatic indicator. J. Paleontol. 59(1): 8-20.

Forester, R.M., 1987. Late Quaternary paleoclimate records from lacustrine ostracodes. In: W.F. Ruddiman and H.E. Wright Jr. (Editors), The Geology of North America, Vol. K-3, North America and adjacent oceans during the last deglaciation. Geol. Soc. Am. pp. 261-276.

Forester, R.M. and Bradbury, J.P., 1981. The paleoenvironmental implications of the ostracodes and diatoms from selected samples in Pliocene and Pleistocene lacustrine sediments in the Beaver Basin, Utah. U.S. Geol. Surv., Openfile Rep., 81-390.

Gonfiantini, R., Bors, S., Ferrara, G. and Panichi, C., 1973. Isotopic composition of waters from the Danakil Depression. Earth Planet. Sci. Lett., 18: 13-21.

Hall, S.A., 1990. Pollen deposition and vegetation in the southern Rocky Mountains and southwest plains, USA. Grana 29: 47-61.

Hanna, T.M. and Harmon, E.J., 1989. An overview of the historical, stratigraphic, and structural setting of the aquifer system of the San Luis Valley. In: E.J. Harmon, (Editor), Water in the valley; A 1989 perspective on water supplies, issues, and solutions in the San Luis Valley, Colorado. 8th annu. field trip. Colo. Ground-water Assoc., pp. 1-34.

Hawley, J.W., 1978. Guidebook to Rio Grande rift in New Mexico and Colorado. New Mex. Bur. Mines Miner. Resour. Circu. 163: 1-241.

Huntley, D., 1979. Cenozoic faulting and sedimentation in northern San Luis Valley, Colorado: summary. Geol. Soc. Am. Bull. Part I, 90: 8-10.

Ingersoll, R.V., Bullard, T.F., Ford, R.L., Grimm, J.P., Pickle, J. D. and Sares, S.W., 1984. The effect of grain size on detrital modes: A text of the Gazzi-Dickinson point-counting method. J. of Sediment. Petrol, 54: 103-116.

Izett, G.A. and Wilcox, R.E., 1982. Ash beds (Pearlette family ash beds) in the western United States and southern Canada. Misc. Invest. Ser., U.S. Geol. Surv., map I-1325.

Jacobson, G.L. and Bradshaw, R.H.W., 1985. The selection of sites for paleovegetational studies. Quat. Res. 16: 80-96.

Jodry, M.A., Shafer, D.S., Stanford, D.J., and Davis, O.K., 1989. Late Quaternary environments and human adaptation in the San Luis Valley, south-central Colorado. In: 
E.J. Harmon (Editor), Water in the valley; A 1989 perspective on water supplies, issues and solutions in the San Luis Valley, Colorado. Colo. Ground-water Assoc., 1989, pp. 189-208.

Keller, G.R., Cordell, L., Davis, G.H., Peeples, W.J. and Whit, G., 1984. A geophysical study of the San Luis Basin. In: New Mex. Geol. Soc. Guidebook of Rio Grande rift: northern New Mexico, 35th Field Conf., pp. 51-57.

Kirkham, R.M. and Rogers, W.P., 1981. Earthquake potential in Colorado. a preliminary evaluation. Color. Geol. Surv. Bull., 43., Open-File Rep., 78-3.

Knepper, D.H. and Marrs, R.W. 1971. Geological development of the Bonanza-San Luis Valley, Sangre de Cristo Range area, south-central Colorado. In: New Mex. Geol. Soc. Guidebook of the San Luis Basin, 22nd Field Conf., pp 249-264.

Kochel, R.C. and Baker, V.R., 1988. Paleoflood analysis using slack water deposits. In: V.R. Baker, R.C. Kochel, and P.C. Patton, (Editors), Flood Geomorphology. New York, Wiley, pp. $357-376$.

Kraus, M.J. and Middleton, L.T., 1987. Contrasting architecture of two alluvial suites in different structural settings. In F.G. Ethridge, R.M. Flores and M.D. Harvey (Editors), Recent developments in fluvial sedimentology. Soc. Econ. Paleontol. Mineral. Spec. Publ. 39: 253-262.

Legg. T.E. and Baker, R.G., 1980. Palynology of Pinedale sediments, Devlins Park, Boulder County, Colorado. Arct. Alp. Res. 12: 319-333.

Lindsay. E.H., Smith, G.A., Haines, C.V. and Opdyke, N.B., 1990. Sediments, geomorphology, magnetostratigraphy and vertebrate paleontology in the San Pedro Valley, Arizona. J. Geol., 98: 605-619

Lipman. P.W., 1975. Evolution of the Platoro caldera complex and related volcanic rocks, southeastern San Juan Mountains, Colorado. U.S. Geol. Surv. Prof. Pap. 852: 1-128.

Maher Jr., L.J., 1963. Pollen analyses of surface materials from the southern San Juan Mountains, Colorado. Geol. Soc. Am. Bull., 74: 1485-1504.

Maher Jr., L.J., 1977. Palynological Studies in the western arm of Lake Superior. Quat. Res., 7: 14-44.

Mankinen, E.A. and Dalrymple, G.B., 1979. Revised geomagnetic polarity time scale for the interval $0-5$ my B.P. J. Geophys. Res. 84: 615-625.

Markgraf, V. and Lennon. T.. 1986. Paleoenvironmental history of the last 13,000 years of the eastern Powder River Basin, Wyoming, and its implication for prehistoric cultural patterns. Plains Anthropol., 31: 1-12.

Markgraf, V. and Scott, L., 1981. Lower timberline in central Colorado during the past 15.000 yr. Geology 9: 231-234.

McAndrews, J.H. and D.M. Power. 1973. Palynology of the Great Lakes: The surface sediments of Lake Ontario. Can. J. Earth Sci. 10: 777-792.

McAndrews, J.H. and Wright Jr., H.E., 1969. Modern pollen rain across the Wyoming basins and the northern Great Plains (U.S.A.). Rev. Paleobot. Palynol., 9: 17-43.

McCalpin, J., 1983. Quaternary geology and neotectonics of the west flank of the northern Sangre de Cristo Mountains, south-central Colorado. Colo. Sch. Mines Q., 77(3): 1-89.

Moran, R.E., 1987. San Luis Valley confined aquifer study (Phase I) executive summary. Prepared for Colorado Water Resources and Power Development Authority, Denver, CO.
Raymo, M.E., Ruddiman, W.F., Bakman. J., Clement, B.M. and Martinson,D.G., 1989. Late Pliocene variation in Northern Hemisphere ice sheets and north Atlantic deep water circulation. Paleoceanography, 4(4): 413-446.

Raymo, M.E., Ruddiman, W.F., Shackleton, N.J.and Oppo, D.W., 1990. Evolution of Atlantic-Pacific $\delta^{13} \mathrm{C}$ gradients over the last 2.5 my Earth Planet. Sci. Lett. 97: 353-368.

Repenning, C.A., 1990. Of mice and ice in the late Pliocene of North America. Arctic 43: 314-323.

Rogers, K.L., Repenning, C.A., Forester, R.M., Larson, E.E., Hall, S.A., Smith, G.R., Anderson, E. and Brown, T.J., 1985. Middle Pleistocene (Late Irvingtonian: Nebraskan) climatic changes in south-central Colorado. Nat. Geogr. Res., 1(4): 535-563.

Rosenbaum, J.G. and Larson, E.E., 1983. Paleomagnetism of two late Pleistocene lake basins in Colorado: an evaluation of detrital remanent magnetization as a recorder of the geomagnetic field. J. Geophys. Res. 88: 10611-10624.

Ruddiman, W.F., Raymo, M. and McIntyre, A., 1986. Matuyama 41,000 year cycles: north Atlantic Ocean and Northern Hemisphere ice sheets. Earth Planet. Sci. Lett., 80: 117-129.

Schuster, M.W. and Steidtmann, J.R., 1987. Fluvial-sandstone architecture and thrust-induced subsidence, northern Green River Basin, Wyoming. In: F.G. Ethridge, R.M. Flores and M.D. Harvey, (Editors), Recent developments in fluvial sedimentology. Soc. Econ. Paleontol. Mineral. Spec. Publ. 39: $279-286$.

Shuey, R.T., Brown, F.H. and Crowes, M.K., 1974. Magnetostratigraphy of the Shungura Formation, southwest Ethiopia: fine structure of the lower Matuyama polarity epoch. Earth Planet. Sci. Lett., 23: 249-260

Siebenthal, C.E., 1910. Geology and water resources of the San Luis Valley, Colorado, Water Supply Paper 240. U.S. Geol. Surv. Gov. Print. Off., Washington, D.C

Siebert, D.J. and Minckley, W.L., 1986. Two new catostomid fishes (Cypriniformes) from the northern Sierra Madre Occidental of Mexico. Am. Mus. Novit., 2849: 1-17.

Stearley, R.F. and Smith, G.R., in prep. Phylogeny of trouts and salmons, Salmoninae, Family Salmonidae.

Stowe, L.G. and Teeri, J.A., 1978. The geographic distribution of $\mathrm{C} 4$ species of the Dicotyledonae in relation to climate. Am. Nat. 112(985): 609-623.

Tarling, D.H., 1983. Paleomagnetism. Chapman and Hall, London, $379 \mathrm{pp}$.

Teeri, J.A. and Stowe, L.G., 1976. Climatic patterns and the distribution of $\mathrm{C} 4$ grasses in North America. Oecologia, 23 : $1-12$.

Thompson, R.A. and Machette, M.N., 1989. Geologic map of the San Luis Hills area, Conejos and Costilla counties, Colorado. U.S. Geol. Surv., Misc. Invest., Map I-1906, scale $1: 50,000$.

Tweto, O. 1979. The Rio Grande rift system in Colorado. In: R.E. Riecker, (Editor), Rio Grande rift: tectonics and magmatism. AGU, Washington, D.C., pp. 33-56.

Van Alstine, R.E., 1968. Tertiary trough between the Arkansas and San Luis Valleys, Colorado. U.S. Geol. Surv. Prof. Pap. 600-C: C158-C160.

Van Alstine, R.E., 1970. Allochthonous Paleozoic blocks in the Tertiary San Luis-upper Arkansas graben. Colorado. U.S. Geol. Surv. Prof. Pap. 700-B: B43-B51. 
Wells, S.G., Kelson, K.I. and Menges, C.M., 1987. Quaternary evolution of fluvial systems in the northern Rio Grande rift New Mexico and Colorado: implication for entrenchement and integration of drainage systems. In: C. Menges, (Editor), Quaternary tectonics, landform evolution, soil chronologies and glacial deposits - northern Rio Grande Rift of New Mexico. Field trip guidebook. Friends of the Pleistocene, Rocky Mountain Cell, pp. 55-69.
Winograd, I.J. 1959. Ground-water conditions and geology of Sunshine Valley, western Taos County, New Mexico. New Mex. State Eng. Off. Tech. Rep. 12, 70 pp.

Wright Jr., H.E., Bent, A.M., Hansen, B.S. and Maher, Jr. L.J., 1973. Present and past vegetation of the Chuska Mountains, northwest New Mexico. Geol. Soc. Am. Bull. 84: 1155-1180. 